\title{
Review \\ Cell Behavior of Non-Small Cell Lung Cancer Is at EGFR and
}

\author{
Sarah Sayed Hassanein ${ }^{1,2, *} \mathbb{0}$, Sherif Abdelaziz Ibrahim ${ }^{2,+}+\mathbb{D}$ and Ahmed Lotfy Abdel-Mawgood $1,+$
}

1 Biotechnology Program, Basic and Applied Sciences (BAS) Institute, Egypt-Japan University of Science and Technology (E-JUST), Alexandria 21934, Egypt; ahmed.mawgood@ejust.edu.eg

2 Department of Zoology, Faculty of Science, Cairo University, Giza 12613, Egypt; isherif@sci.cu.edu.eg

* Correspondence: sarah.hassanein@ejust.edu.eg or ssara@sci.cu.edu.eg; Fax: +20-3-4600004

+ The authors have contributed equally to this work and senior authorship.

check for updates

Citation: Hassanein, S.S.; Ibrahim,

S.A.; Abdel-Mawgood, A.L. Cell

Behavior of Non-Small Cell Lung Cancer Is at EGFR and MicroRNAs Hands. Int. J. Mol. Sci. 2021, 22, 12496. https://doi.org/10.3390/

ijms222212496

Academic Editor: Carlo Genova

Received: 1 November 2021

Accepted: 17 November 2021

Published: 19 November 2021

Publisher's Note: MDPI stays neutral with regard to jurisdictional claims in published maps and institutional affiliations.

Copyright: (c) 2021 by the authors. Licensee MDPI, Basel, Switzerland. This article is an open access article distributed under the terms and conditions of the Creative Commons Attribution (CC BY) license (https:/ / creativecommons.org/licenses/by/ $4.0 /)$.

\begin{abstract}
Lung cancer is a complex disease associated with gene mutations, particularly mutations of Kirsten Rat Sarcoma Viral Oncogene Homolog (KRAS) and epidermal growth factor receptor (EGFR). Non-small cell lung cancer (NSCLC) and small cell lung cancer (SCLC) are the two major types of lung cancer. The former includes most lung cancers $(85 \%)$ and are commonly associated with EGFR mutations. Several EGFR-tyrosine kinase inhibitors (EGFR-TKIs), including erlotinib, gefitinib, and osimertinib, are effective therapeutic agents in EGFR-mutated NSCLC. However, their effectiveness is limited by the development (acquired) or presence of intrinsic drug resistance. MicroRNAs (miRNAs) are key gene regulators that play a profound role in the development and outcomes for NSCLC via their role as oncogenes or oncosuppressors. The regulatory role of miRNAdependent EGFR crosstalk depends on EGFR signaling pathway, including Rat Sarcoma/Rapidly Accelerated Fibrosarcoma/Mitogen-Activated Protein Kinase/Extracellular Signal-Regulated Kinase 1/2 (Ras/Raf/MEK/ERK1/2), Signal Transducer and Activator of Transcription (STAT), Nuclear Factor Kappa-Light-Chain-Enhancer of Activated B Cells (NF-kB), phosphoinositide 3-kinase/protein kinase B (PI3K/AKT), Janus kinase 1 (JAK1), and growth factor receptor-bound protein 2 (GRB2). Dysregulated expression of miRNAs affects sensitivity to treatment with EGFR-TKIs. Thus, abnormalities in miRNA-dependent EGFR crosstalk can be used as diagnostic and prognostic markers, as well as therapeutic targets in NSCLC. In this review, we present an overview of miRNA-dependent EGFR expression regulation, which modulates the behavior and progression of NSCLC.
\end{abstract}

Keywords: epidermal growth factor receptor (EGFR); microRNA (miRNA); therapeutic targets; diagnostic markers; signaling pathways; oncogenes; oncosuppressors; chemoresistance; tyrosine kinase inhibitors (TKIs); non-small cell lung cancer (NSCLC)

\section{Introduction}

Globally, lung cancer is the foremost cancer type in terms of incidence and mortality rates in men and women [1-3]. It is classified into small cell lung cancer (SCLC) and non-small cell lung cancer (NSCLC), with approximately $15 \%$ and $85 \%$ of lung cancer cases, respectively [4-6]. Despite progress in treatment strategies of NSCLC, the overall five-year survival rate is still poor due to late diagnosis and drug resistance development, particularly to tyrosine kinase inhibitors (TKIs) [2,7-9]. Receptor tyrosine kinases (RTKs), namely epidermal growth factor receptor (EGFR), are commonly overexpressed in NSCLC and associated with poor prognosis $[10,11]$. The signaling pathway of EGFR activates intracellular signaling cascades, including Signal Transducer and Activator of Transcription (STAT), Rat Sarcoma/Rapidly Accelerated Fibrosarcoma/Mitogen-Activated Protein Kinase/Extracellular Signal-Regulated Kinase 1/2 (Ras/Raf/MEK/ERK1/2), phospholipase C (PLC)/protein kinase C (PKC), and phosphoinositide 3-kinase/phosphoinositide 3-kinase/Protein kinase B (PI3K/Akt) pathways that boost angiogenesis, tumor cell proliferation, metastasis, invasion, and apoptosis evasion [10,12-16] (Figure 1). In lung cancer 
cells, the expression of EGFR and their ligands, especially transforming growth factor-alpha $(\mathrm{TGF} \alpha)$, signifies the presence of a self-stimulatory (autocrine) growth factor loop [17]. For in-depth molecular signaling pathways of EGFR, we refer the readers to recent reviews $[11,18]$.

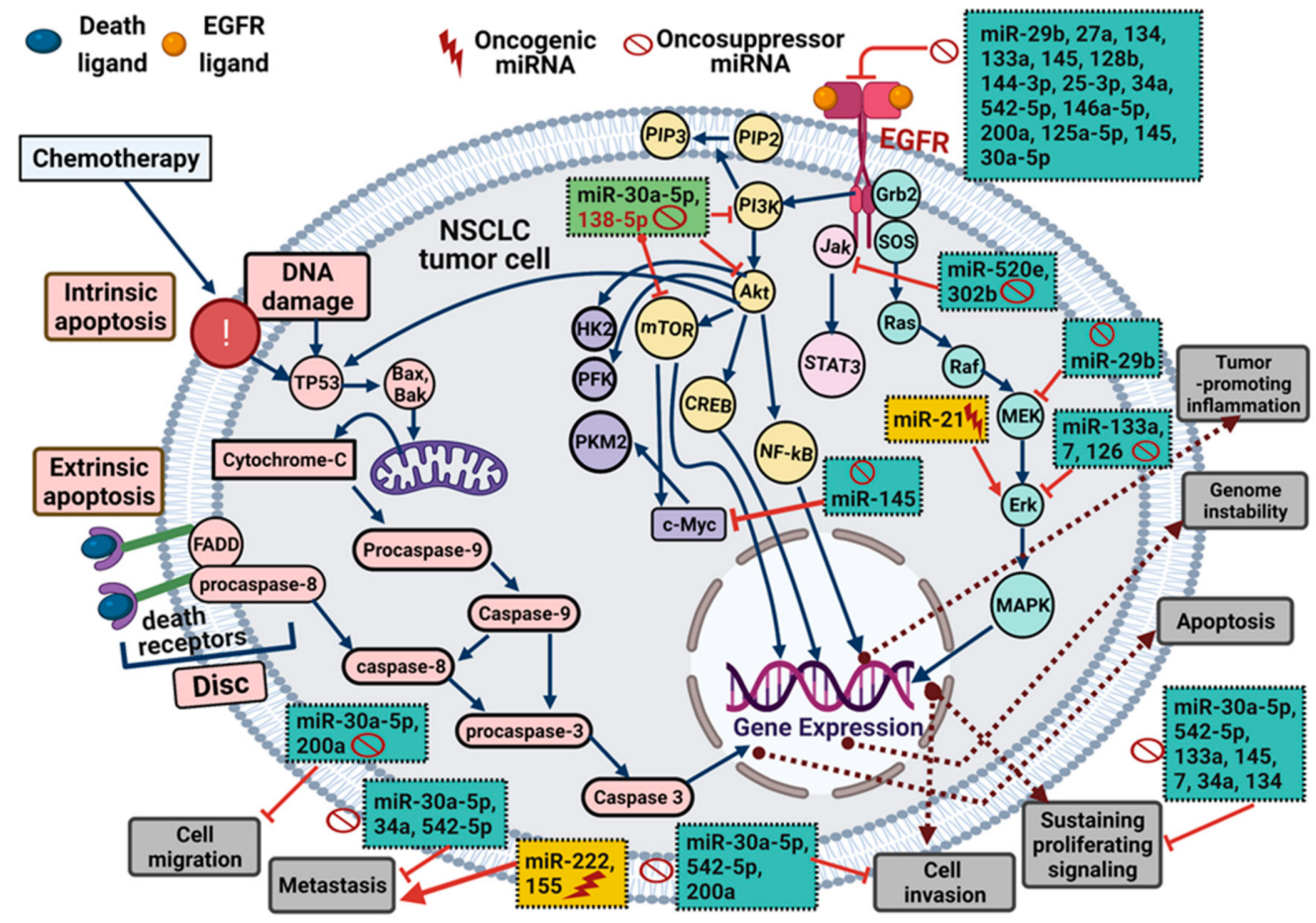

Figure 1. EGFR signaling components are affected by various miRNAs (oncogenic or tumor suppressors) in non-small cell lung cancer. Activation of the EGFR signaling pathway, including PI3K/Akt, Ras/Raf/MAPK, and Jak/STAT, stimulates inflammation, proliferative signaling, migration, angiogenesis, and invasion. These signaling pathways are controlled by different miRNAs. Binding of death ligand (e.g., TRAIL) to death receptor leads to FADD (adaptor molecule). Pro-caspase-8 activation takes place upon its binding to FADD and DISC formation (extrinsic apoptosis). Chemotherapeutic drugs, such as cisplatin, cause DNA damage and results in p53 activation (intrinsic apoptosis). Activated caspase- 8 directly activates other caspases that translocate to the mitochondria promoting the Bax-Bak assembly, thus changing mitochondrial membrane permeability. Cytochrome $\mathrm{c}$ is then released into cytosol resulting in caspases activation leading to apoptosis. Several oncogenic and tumor suppressor miRNAs control EGFR signaling components and subsequently affect tumor growth and progression. Blue and red arrows for stimulation, dashed brown arrows for cellular effect, and red " $\mathrm{T}$ " for inhibition.

MicroRNAs (miRNAs) are known as small non-coding RNAs consisting of 18-25 nucleotides and are nodal post-transcriptional gene regulators [19-21]. Individual miRNA plays a key role in targeting and regulating many mRNAs expression either by promoting mRNAs degradation or inhibiting their translation. Thus, individual mRNA can be regulated by several miRNAs $[15,22-24]$. Aberrant miRNAs expression patterns can be used as diagnostic and prognostic markers in NSCLC [4,8,25-28]. MiRNA-mRNA interactions are associated with many biological hallmarks of lung cancer $[24,29,30]$. Dysregulated expression of miRNAs represents a hallmark of several human cancers, including lung cancer, acting as oncogenes or tumor suppressors [5,20,21,31,32]. EGFR signaling pathways and miRNAs are key players in the development of NSCLC [31,33-36]. The dual role of miRNAs, either as oncogenes or oncosuppressors, has been revealed in different studies, and that basically depends on their direct targets and the activated downstream signaling pathways [37-40]. Interestingly, the transduction of bronchial epithelial BEAS-2B cells with retroviral vectors expressing KRAS ${ }^{\mathrm{G} 12 \mathrm{~V}}$ (Kirsten Rat Sarcoma Viral Oncogene Homolog) and monitoring miRNA expression patterns by microarray analysis was performed to identify miRNAs implicated in EGFR signaling in NSCLC patients. This approach could define miR-29b as an important target for upregulation by mutant KRAS, wherein the 
pharmacologic inhibition of EGFR or MEK was sufficient to reduce miR-29b expression levels. Anti-miR-29b constructs increased apoptosis sensitivity, implying that mutant KRAS conferred apoptotic resistance by miR-29b [41-43]. The ability of miR-29b to mediate this effect was ascribed to targeting TNFAIP3/A20, a negative regulator of NF- $\mathrm{kB}$ signaling. Overexpression of a miR-29b-refractory isoform of TNFAIP3 restored NF- $\mathrm{kB}$ and extrinsic apoptosis, proving that TNFAIP3 is a functionally important target for miR-29b. Further, miR-29b confers sensitivity to intrinsic apoptosis induced by cisplatin exposure. Thus, miR-29b expression can cause cells to shift from extrinsic to intrinsic apoptosis mechanisms. From these data, miR-29b can act as an oncogene or a tumor suppressor gene, depending on the signaling context [41,43-46]. In the next sections, we comprehensively discuss the reciprocal regulation of miRNAs and EGFR expression and activation and how this regulation affects NSCLC behavior.

\section{EGFR Overexpression/Hyperactivation and miRNA Expression Pattern: Effects on NSCLC Cell Behavior}

\subsection{Effect of miRNAs on EGFR Expression}

Emerging data suggest that EGFR mRNA is overexpressed in a variety of human tumors, including NSCLC, and is involved in tumor growth [47-51]. The behavior of lung cancer cells is associated with miRNA-dependent EGFR expression (Table 1). For instance, EGFR and c-MET (receptor for hepatocyte growth factor) are implicated in various cellular processes and regulated by many miRNAs, leading to tumor progression [52-54]. A biological relationship between EGFR, MET, and the miRNA cluster 23a $\sim 27 \mathrm{a} \sim 24-2$ was unveiled, where miR-27a regulated MET, EGFR, and Sprouty2 in a panel of NSCLC cell lines (293, 293TN, H460, A549, H1299). According to these findings, miR-27a could downregulate MET and EGFR by targeting their $3^{\prime}$ UTRs directly or indirectly through Sprouty2; consequently, the underlying mechanism of the MET and EGFR axis regulation may emerge as new strategies in lung cancer treatment [52,53]. EGFR was also a direct target of miR134, evidenced by luciferase assays, and the overexpression of miR-134 suppressed EGFR expression in NSCLC cells $[36,55,56]$. Likewise, EGFR was a direct target of miR-34a, and the siRNA knockdown of EGFR inhibited cell proliferation, promoted apoptosis, and suppressed cell cycle progression. Using quantitative real-time PCR (qRT-PCR) analysis, miR-34a expression was significantly reduced in carcinoma tissues and cell lines of NSCLC, implying that miR-34a can be a tumor suppressor in lung cancer. Furthermore, in both the A549 xenograft model and metastatic tumors in nude mice, miR-34a inhibits tumor development [57-63].

Table 1. Role of miRNAs via targeting EGFR or its downstream signaling in modulating lung cancer cell behavior in preclinical models and clinical specimens.

\begin{tabular}{|c|c|c|c|c|}
\hline Type of miRNA & $\begin{array}{l}\text { Proposed Mechanism of Action } \\
\text { in Lung Cancer }\end{array}$ & $\begin{array}{l}\text { Preclinical and } \\
\text { Clinical Studies }\end{array}$ & Methodology & Reference \\
\hline \multicolumn{5}{|c|}{ Oncosuppressor miRNAs } \\
\hline $\operatorname{miR}-27 a$ & $\begin{array}{l}\text { - } \quad \text { Regulation of MET and } \\
\text { EGFR axis }\end{array}$ & $\begin{array}{c}\text { A549, H1299, and } \\
\text { CALU-1 NSCLC cell } \\
\text { lines }\end{array}$ & $\begin{array}{c}\text { qRT-PCR } \\
\text { Western blot } \\
\text { Luciferase reporter } \\
\text { assay }\end{array}$ & [52] \\
\hline miR-133a & $\begin{array}{ll}\text { - } & \text { Suppressing EGFR, p-ERK, } \\
\text { and p-AKT } \\
\text { - } \quad \text { Augmenting caspase-3 } \\
\text { protein expression } \\
\text { - } \quad \text { Inducing apoptosis; } \\
\text { repressing cell growth }\end{array}$ & $\begin{array}{l}\text { Human NSCLC tissues } \\
\text { and adjacent normal } \\
\text { lung tissue } \\
\text { H358 human NSCLC } \\
\text { cell line transfected } \\
\text { with miR-133a mimics }\end{array}$ & $\begin{array}{c}\text { qRT-PCR } \\
\text { Immunohistochemistry } \\
\text { (IHC) }\end{array}$ & [64-66] \\
\hline
\end{tabular}


Table 1. Cont.

\begin{tabular}{|c|c|c|c|c|}
\hline Type of miRNA & $\begin{array}{l}\text { Proposed Mechanism of Action in } \\
\text { Lung Cancer }\end{array}$ & $\begin{array}{l}\text { Preclinical and } \\
\text { Clinical Studies }\end{array}$ & Methodology & Reference \\
\hline $\operatorname{miR}-25-3 p$ & $\begin{array}{l}\text { - Prognostic biomarker in } \\
\text { NSCLC by regulating TGF } \beta \\
\text { and EGFR signaling }\end{array}$ & $\begin{array}{l}\text { miRNA regression } \\
\text { model supported by } \\
\text { target prediction } \\
\text { databases }\end{array}$ & $\begin{array}{l}\text { Multiple linear } \\
\text { regression based on } \\
\text { expression levels }\end{array}$ & [8] \\
\hline $\operatorname{miR}-128 b$ & $\begin{array}{l}\text { - } \quad \text { Regulating the expression of } \\
\text { EGFR }\end{array}$ & $\begin{array}{l}\text { Human NSCLC and } \\
\text { adjacent normal lung } \\
\text { tissue samples }\end{array}$ & $\begin{array}{c}\text { qRT-PCR } \\
\text { Semi-quantitative } \\
\text { RT-PCR } \\
\text { IHC analysis }\end{array}$ & [49] \\
\hline miR-134 & $\begin{array}{ll}\text { - } & \text { Repressing EGFR-related } \\
\text { signaling pathways } \\
\text { - } & \text { Inhibiting NSCLC cell } \\
\text { proliferation by promoting } \\
\text { apoptosis and/or cell cycle } \\
\text { arrest }\end{array}$ & $\begin{array}{l}\text { NSCLC cell lines } \\
\text { (A549, H1299, H520, } \\
\text { and H1975) }\end{array}$ & $\begin{array}{c}\text { qRT-PCR } \\
\text { MTT assay } \\
\text { Flow cytometry } \\
\text { Luciferase reporter } \\
\text { assay } \\
\text { RNAi and rescue } \\
\text { experiments } \\
\text { A549 xenograft in nude } \\
\text { mice }\end{array}$ & {$[36]$} \\
\hline miR-34a & 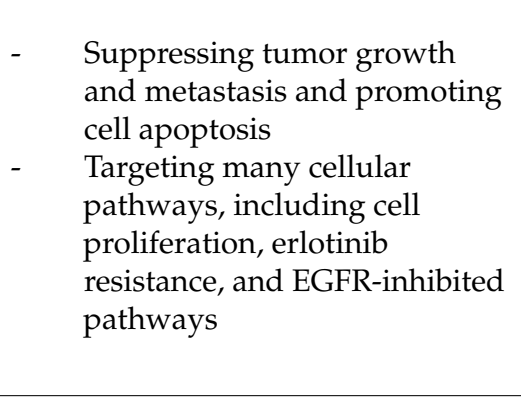 & $\begin{array}{c}\text { Human NSCLC and } \\
\text { adjacent normal lung } \\
\text { tissue samples } \\
\text { A549 (EGFR-wild } \\
\text { type), SPC-A1 and } \\
\text { HCC827 } \\
\text { (EGFR-mutated) cell } \\
\text { lines } \\
\text { lung carcinoma } \\
\text { xenograft mouse model }\end{array}$ & $\begin{array}{c}\text { qRT-PCR } \\
\text { Cell proliferation assay } \\
\text { Cell transwell assay } \\
\text { Luciferase reporter } \\
\text { assay } \\
\text { Western blot analysis } \\
\text { xenograft assay } \\
\text { IHC analysis }\end{array}$ & {$[20,57]$} \\
\hline miR-542-5p & $\begin{array}{l}\text { Associated with EGFR, } \\
\text { vascular invasion, advanced } \\
\text { TNM stage, lymphatic } \\
\text { metastasis, and patients' poor } \\
\text { prognosis }\end{array}$ & $\begin{array}{l}\text { Human NSCLC and } \\
\text { adjacent normal lung } \\
\text { tissue samples }\end{array}$ & qRT-PCR & [67] \\
\hline miR-146a-5p & $\begin{array}{ll}\text { - } & \text { Targeted EGFR and NF- } \mathrm{kB} \\
\text { signaling } \\
\text { - } \\
\text { Decreasing cellular expression } \\
\text { and release of CCL2, a } \\
\text { chemokine }\end{array}$ & A549 cells & $\begin{array}{c}\text { RNA-Seq } \\
\text { Gene ontology analysis } \\
\text { qRT-PCR }\end{array}$ & [68] \\
\hline $\begin{array}{l}\operatorname{miR}-183 \\
\operatorname{miR}-210 \\
\operatorname{miR}-34 c\end{array}$ & $\begin{array}{ll}\text { - } & \text { Correlated with } \\
\text { lymphovascular invasion } \\
\text { - } \quad \begin{array}{l}\text { Independently associated with } \\
\text { T stage }\end{array} \\
\text { - } \quad \text { High expression exhibited } \\
\text { poor overall survival in the } \\
\text { exon } 19 \text { mutated EGFR group } \\
\text { All } 3 \text { miRNAs were related to } \\
\text { poor tumor differentiation }\end{array}$ & $\begin{array}{l}\text { Human mutated LADC } \\
\text { and adjacent normal } \\
\text { lung tissue samples }\end{array}$ & $\begin{array}{l}\text { Microarray analysis } \\
\text { qRT-PCR }\end{array}$ & [25] \\
\hline
\end{tabular}


Table 1. Cont.

\begin{tabular}{|c|c|c|c|c|}
\hline Type of miRNA & $\begin{array}{l}\text { Proposed Mechanism of Action in } \\
\text { Lung Cancer }\end{array}$ & $\begin{array}{l}\text { Preclinical and } \\
\text { Clinical Studies }\end{array}$ & Methodology & Reference \\
\hline $\operatorname{miR}-125 b$ & $\begin{array}{ll}\text { - } & \text { Predicting EGFR mutational } \\
\text { status and gefitinib-sensitivity } \\
\text { - } & \text { Associated with disease-free } \\
\text { survival and overall survival }\end{array}$ & $\begin{array}{l}\text { Human NSCLC and } \\
\text { adjacent normal lung } \\
\text { tissue samples } \\
\text { and plasma } \\
\text { gefitinib-sensitive PC9, } \\
\text { and gefitinib-resistant } \\
\text { A549 and H1299 } \\
\text { human lung ADC cells }\end{array}$ & $\begin{array}{l}\text { MicroRNA array } \\
\text { Genotyping of EGFR } \\
\text { mutational status }\end{array}$ & [69] \\
\hline miR-30a-5p & $\begin{array}{l}\text { Suppressing cell proliferation, } \\
\text { migration, invasion, and EMT }\end{array}$ & $\begin{array}{l}\text { Human NSCLC and } \\
\text { adjacent normal lung } \\
\text { tissue samples } \\
\text { lung carcinoma } \\
\text { xenograft mouse model }\end{array}$ & $\begin{array}{l}\text { CCK-8 and clonogenic } \\
\text { assays } \\
\text { Wound healing, } \\
\text { migration and invasion } \\
\text { assays }\end{array}$ & [70] \\
\hline miR-145 & $\begin{array}{ll}\text { - } & \text { Inhibiting EGFR expression } \\
- & \text { Improving the sensitivity to } \\
\text { erlotinib } \\
\text { - } & \text { Cell proliferation and survival } \\
\text { - } & \text { Inhibition of cell growth in the } \\
& \text { EGFR mutant lung } \\
\text { adenocarcinoma } \\
\text { - } & \begin{array}{l}\text { Induced cell arrest of G1/S } \\
\text { cycle phase }\end{array}\end{array}$ & NSCLC cell line A549 & $\begin{array}{c}\text { qRT-PCR } \\
\text { Trypan blue and MTT } \\
\text { assays } \\
\text { ELISA cell death assay } \\
\text { Combination effect } \\
\text { analysis }\end{array}$ & [71] \\
\hline miR-200a & $\begin{array}{l}\text { Downregulating EGFR and } \\
\text { c-Met levels and inhibited } \\
\text { invasion, migration, and } \\
\text { gefitinib resistance }\end{array}$ & $\begin{array}{l}\text { lung cancer cell lines } \\
\text { H3255 (L858R EGFR } \\
\text { allele), H1975 } \\
\text { (L858R/T790M } \\
\text { mutations in EGFR), } \\
\text { and HCC827 }\end{array}$ & $\begin{array}{c}\text { qRT-PCR } \\
\text { Luciferase assays } \\
\text { Western Blot } \\
\text { Wound-Healing Assay } \\
\text { Cell Invasion Assay } \\
\text { MTS assay and BrdU } \\
\text { incorporation assay }\end{array}$ & [1] \\
\hline miR-125a-5p & 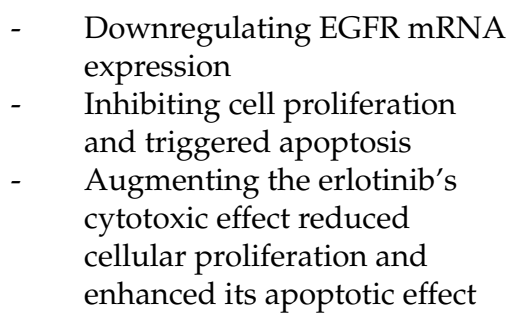 & A549 lung cancer cells & $\begin{array}{c}\text { qRT-PCR } \\
\text { Trypan blue assays } \\
\text { MTT assay } \\
\text { Combination index } \\
\text { (Chou-Talalay) } \\
\text { ELISA cell death assay } \\
\text { kit }\end{array}$ & [72] \\
\hline $\operatorname{miR}-30 a-5 p$ & $\begin{array}{ll}\text { - } & \text { Targeting EGFR and IGF-1R } \\
\text { signaling pathways } \\
\text { - } \quad \text { Regulating PI3K/AKT } \\
\text { signaling pathway } \\
\text { - } \quad \text { Promoting cell apoptosis, } \\
\text { impeding cell migration and } \\
\text { invasion properties, and } \\
\text { reducing gefitinib resistance }\end{array}$ & $\begin{array}{l}\text { Gefitinib-resistant } \\
\text { NSCLC cell lines, H460 } \\
\text { and H1975 }\end{array}$ & $\begin{array}{c}\text { Western Blot } \\
\text { Annexin V-FITC } \\
\text { Apoptosis } \\
\text { Detection Kit } \\
\text { CytoSelect }{ }^{\mathrm{TM}} \text { Cell } \\
\text { Invasion Assay Kit } \\
\text { Wound healing assay }\end{array}$ & {$[15,73]$} \\
\hline
\end{tabular}


Table 1. Cont.

\begin{tabular}{|c|c|c|c|c|}
\hline Type of miRNA & $\begin{array}{l}\text { Proposed Mechanism of Action in } \\
\text { Lung Cancer }\end{array}$ & $\begin{array}{l}\text { Preclinical and } \\
\text { Clinical Studies }\end{array}$ & Methodology & Reference \\
\hline let- $7 \mathrm{~b}$ & 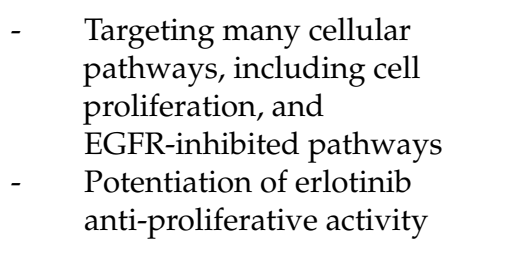 & $\begin{array}{l}\text { NSCLC cells bearing } \\
\text { clinically relevant } \\
\text { mutations in KRAS and } \\
\text { TP53 (H358, H23, H441, } \\
\text { Calu-6) or NRAS and } \\
\text { TP53 (H1299) }\end{array}$ & $\begin{array}{l}\text { qRT-PCR } \\
\text { Sulforhodamine B } \\
\text { (SRB) assays }\end{array}$ & {$[20,49]$} \\
\hline $\operatorname{miR}-200 c-3 p$ & $\begin{array}{l}\text { - } \quad \text { Increasing sensitivity to } \\
\text { EGFR-TKIs in EGFR mutant } \\
\text { NSCLC by modifying the EMT } \\
\text { process }\end{array}$ & $\begin{array}{c}\text { EGFR-mutant NSCLC } \\
\text { and adjacent normal } \\
\text { lung tissue } \\
\text { EGFR TKI-sensitive cell } \\
\text { lines- PC9 and HCC287, } \\
\text { and gefitinib-resistant } \\
\text { PC9/gef cells that } \\
\text { harbor a deletion in } \\
\text { exon } 19 \text { of EGFR }\end{array}$ & $\begin{array}{l}\text { MicroRNA array } \\
\text { qRT-PCR } \\
\text { Western Blot } \\
\text { Migration assay } \\
\text { Cytotoxicity and } \\
\text { apoptosis assays }\end{array}$ & [74] \\
\hline miR-762 & $\begin{array}{l}\text { - Gefitinib resistance and poor } \\
\text { prognosis of } \\
\text { post-chemotherapy } \\
\text { IL-6 signaling-induced } \\
\text { miR-762 upregulation } \\
\text { improved cell survival and } \\
\text { retained NSCLC cells' } \\
\text { resistance to gefitinib }\end{array}$ & $\begin{array}{c}\text { NSCLC Cell lines with } \\
\text { EGFR mutations } \\
\text { PC-9 (E746-A750 del) } \\
\text { NCI-H820 (E746-E749 } \\
\text { del) } \\
\text { NCI-H1650 (E746-A750 } \\
\text { del) } \\
\text { NCI-H1975 (L858R) } \\
\text { A549, NCI-H2170, } \\
\text { NCI-H1993, } \\
\text { NCI-H2126, } \\
\text { NCI-H1299, } \\
\text { NCI-H1648, } \\
\text { NCI-H1703 and } \\
\text { NCI-H2347 (WT) } \\
\text { lung carcinoma } \\
\text { xenograft mouse model }\end{array}$ & $\begin{array}{c}\text { qRT-PCR } \\
\text { Cytotoxicity } \\
\text { In vivo } \\
\text { chemosensitivity } \\
\text { Luciferase reporter } \\
\text { assay }\end{array}$ & [75] \\
\hline $\operatorname{miR}-126$ & $\begin{array}{ll}\text { - } & \text { Suppression of Akt and ERK } \\
\text { activation } \\
\text { - } & \text { Suppressing cell growth; } \\
\text { inhibited cell proliferation } \\
\text { - } \quad \text { Enhanced gefitinib-induced } \\
\text { cytotoxicity }\end{array}$ & $\begin{array}{c}\text { NCI-H460 (H460) and } \\
\text { A549 cells } \\
\text { lung carcinoma } \\
\text { xenograft mouse model }\end{array}$ & $\begin{array}{c}\text { qRT-PCR } \\
\text { Growth inhibition } \\
\text { assay } \\
\text { Western Blot }\end{array}$ & [19] \\
\hline miR-138-5p & $\begin{array}{l}\text { - Increasing the sensitivity to } \\
\text { gefitinib }\end{array}$ & $\begin{array}{l}\text { Human NSCLC and } \\
\text { adjacent normal lung } \\
\text { tissue samples } \\
\text { NSCLC cell lines PC9 } \\
\text { and H1975 }\end{array}$ & $\begin{array}{c}\text { qRT-PCR } \\
\text { Luciferase assays } \\
\text { Western Blot } \\
\text { IHC }\end{array}$ & [76] \\
\hline \multicolumn{5}{|c|}{ Oncogenic miRNAs } \\
\hline
\end{tabular}


Table 1. Cont.

\begin{tabular}{|c|c|c|c|c|}
\hline Type of miRNA & $\begin{array}{l}\text { Proposed Mechanism of Action in } \\
\text { Lung Cancer }\end{array}$ & $\begin{array}{l}\text { Preclinical and } \\
\text { Clinical Studies }\end{array}$ & Methodology & Reference \\
\hline $\operatorname{miR}-147 \mathrm{~b}$ & 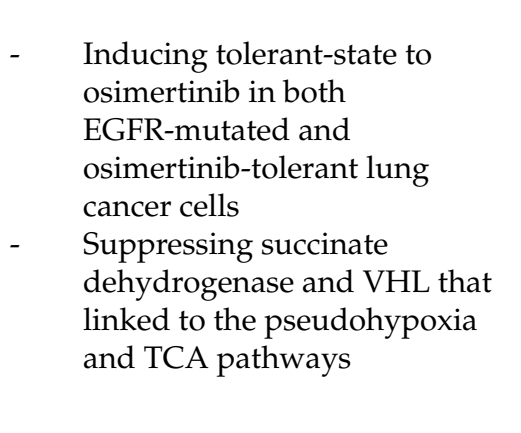 & $\begin{array}{c}\text { EGFR-wild type cell } \\
\text { lines H358, H460, A549, } \\
\text { H1299, and H69 } \\
\text { (ATCC) } \\
\text { EGFR-mutant cell lines } \\
\text { H1650, H1975, HCC827, } \\
\text { HCC827GR, PC9, } \\
\text { PC9ER, and H3255 } \\
\text { Patient-derived } \\
\text { Xenograft Tumor } \\
\text { Specimens }\end{array}$ & $\begin{array}{c}\text { MicroRNA array } \\
\text { Colony Formation } \\
\text { Assay } \\
\text { High-Throughput } \\
\text { Sequencing } \\
\text { Western Blot } \\
\text { H\&E Staining and } \\
\text { Immunofluorescence. } \\
\text { Targeted Mass } \\
\text { Spectrometry. }\end{array}$ & [77] \\
\hline $\operatorname{miR}-21$ & $\begin{array}{l}\text { Reinforcing the aberrant } \\
\text { regulation linked to lung } \\
\text { carcinogenesis in } \\
\text { never-smokers } \\
\text { More dramatic expression } \\
\text { changes in EGFR-mutated } \\
\text { patient mutations as opposed } \\
\text { to EGFR wild-type cases } \\
\text { A strong association between } \\
\text { p-EGFR and miR-21 levels and } \\
\text { the suppression of miR-21 by } \\
\text { the EGFR-TKI AG1478 }\end{array}$ & $\begin{array}{ll}- & \text { Data set } \\
\text { - } & \text { NSCLC patients } \\
& \text { with EGFR } 19 \\
\text { deletion } \\
\text { - } \quad \text { Another cohort } \\
\text { with EGFR 19 } \\
\text { deletion } \\
\text { mutations, who } \\
\text { had dramatically } \\
\text { different } \\
\text { responses to } \\
\text { EGFR-TKI (for } \\
\text { miRNA } \\
\text { expression } \\
\text { validation) }\end{array}$ & $\begin{array}{c}\text { Gene expression data } \\
\text { (target scan database) } \\
\text { qRT-PCR }\end{array}$ & [78-80] \\
\hline
\end{tabular}

\section{Oncogenic/Oncosuppressor miRNAs}

- $\quad$ Targeting TNFAIP3/A20

(NF- $\mathrm{KB}$ negative regulator)

- $\quad$ miR-29b-refractory isoform of

miR-29b TNFAIP3 restored NF- $\mathrm{kB}$ and extrinsic apoptosis

- $\quad$ confers sensitivity to intrinsic apoptosis induced by cisplatin exposure.

$\begin{array}{cc}\text { mutated } K R A S^{\mathrm{G} 12 \mathrm{~V}} & \text { Microarray analysis } \\ \text { Cells } & \text { Mechanistic } \\ & \text { investigations }\end{array}$

- $\quad$ Enhanced phosphorylation of c-Myc and EGFR in EGFR mutant (L858R), (CL1-5 cells), promoting miR-7 expression

- $\quad$ EGFR prompts miR-7 expression via Ras/ERK/Myc pathway

miR-7 - $\quad$ Reducing the ERF level; inducing cell growth and tumor formation; raising the mortality rate

- $\quad$ Repressing cell proliferation, tumorigenicity; tempting cell apoptosis

- $\quad$ Downregulating EGFR and RAF-1 expression
EGFR-silenced cells

EGFR mutant (L858R) CL1-5 cells.
MiRNA microarray
analysis
qRT-PCR

$[81,82]$ 
A mRNA-miRNA stepwise regression model and database-dependent miRNA target prediction were performed to identify the miRNA-dependent EGFR signaling cascade. This model revealed that the EGFR ligand EGF is positively correlated with circulating miR145 and miR-199a-5p in the pre-surgery and post-surgery NSCLC patients, respectively. Unexpectedly, miR-495 was positively related to PTK2 in both groups [4]. Thus, it can be inferred that miRNAs can regulate different components of the EGFR signaling pathway, namely ligand, receptor, or the downstream signaling molecules [10,12-16,22-24]. In this regard, the expression of miR-133a in NSCLC tissue was found to be lower than in adjacent mucosae. Furthermore, as compared to the adjacent mucosae, NSCLC tissue had higher EGFR expression. Besides, the upregulation of miR-133a inhibited cell growth and induced apoptosis in NSCLC cells, which in turn increased caspase-3 protein expression, while suppressing EGFR, phosphorylated (p)-AKT, and phosphorylated (p)-ERK (Figure 1). These findings shed light on the function of miR-133a and the molecular mechanisms underlying miR-133a-mediated EGFR/AKT/ERK signaling pathway downregulation in NSCLC [64-66]. Further, miR-145 significantly suppressed EGFR expression and inhibited cancer cell growth compared with negative control miRNA in A549 NSCLC cells $[7,83,84]$. Transfection with miR-146a mimic in NSCLC cells resulted in the downregulation of EGFR mRNA. Meanwhile, inverse results were observed when transfected with miR-146a inhibitor. Furthermore, high miR-146a expression showed longer progression-free survival in tissues of NSCLC patients. As a result, miR-146a is a potent prognostic biomarker in NSCLC [85-87]. Moreover, the expression levels of miR-128b were lower in NSCLC carcinoma tissues than in adjacent non-neoplastic tissues, whereas the expression of EGFR mRNA was the opposite. According to immunohistochemical staining analysis, normal tissues did not express EGFR protein, and cancer tissues exhibited a $60 \%$ positive staining for EGFR. Furthermore, the relative expression of miR-128b levels was negatively correlated with EGFR mRNA and protein levels [49,88-92].

MiR-7 is an important modulator of EGFR-mediated oncogenesis [81,82,93,94]. Knockdown of EGFR mediated by short hairpin RNA (shRNA)-bearing lentiviruses induced enlarged cell size and growth arrest in CL1-5 lung cancer cells. MiRNA microarray analysis for these EGFR-silenced cells showed a significant downregulation of miR-7 confirmed by both qRT-PCR analysis and the RNase protection assay. In contrast, expression of the EGFR mutant (L858R), which enhanced phosphorylation of c-Myc and EGFR, promoted the expression of miR-7 in CL1-5 cells. These data indicated that miR-7 is induced by EGFR signaling via a Ras/ERK/Myc pathway $[82,95,96]$ (Table 1). On the contrary, Zhang et al. reported the tumor suppressor effect of circular RNA ciRS-7 (CDR1as)/miR-7 signals. CDR1as levels significantly increased with the development of NSCLC cells and tissues, which was inversely correlated with miR-7 expression. The CDR1as overexpression resulted in increased cell vitality and development, which could be reversed by knockdown CDR1as or overexpressing miR-7, inducing apoptosis and G1/S arrest. CDR1as acted as miR-7 sponges, allowing up-regulation of direct miR-7 target genes, such as EGFR, CCNE1, and PIK3CD. The findings in vivo further indicated that CDR1as acted as an oncogene, upregulating the proliferation index Ki-67, EGFR, CCNE1, and PIK3CD levels, thus inhibiting the anti-tumor effects of tumor suppressor miR-7 [94-97]. This is supported by the finding of decreased miR-7 expression quantified by qRT-PCR in murine Lewis lung cancer (3LL) cells [81]. Further, miR-7 expression restoration in vitro induced cell apoptosis, prevented 3LL cell proliferation, and decreased tumorigenesis in vivo. Using qRT-PCR and Western blot analysis, miR-7 has been shown to suppress the expression of both oncogenes, the murine leukemia viral oncogene homolog-1 (RAF-1), a downstream effecter of EGFR signaling, and EGFR [94-97]. Furthermore, in 3LL cells, EGFR inhibition had similar effects of transfection with miR-7 mimic. These data revealed that miR-7 functions as an anti-tumor miRNA in 3LL cells by targeting the expression of the oncogenes EGFR and RAF-1 [81].

A study by Giordano et al. analyzed the expression of RNA in NSCLC tissues, including small RNAs using nCounter System ${ }^{\circledR}$ (NanoString Technologies) to better understand the molecular features of young and old lung adenocarcinoma (LADC) patients. Seven 
miRNAs were found to be differentially expressed in the two groups; miR-25-3p, miR-33a$5 p$, miR-29c-3p, miR-153-3p, miR-144-3p, miR-342-5p, and miR-485-3p. The expression levels of these miRNAs were higher in NSCLC tissues of young patients than in older counterparts. Their predicted genes include EGFR, MET, VEGF-A, TP53, and PDGFRa. MiR-144-3p had the opposite effect on overall survival, where its upregulation was linked to a worse prognosis in young patients and a better prognosis in older patients [26,98-100]. Furthermore, an enrichment analysis explored 33 aberrantly expressed miRNAs in LADC and LSCC, of which miR-25-3p was a prospective prognostic biomarker in NSCLC by regulating TGF $\beta$ and EGFR signaling [8,101-105]. It has been recently reported that six differentially expressed miRNAs, including miR-31-5p, $-5 p$, miR-708-5p, miR-451a, miR$30 a-5 p$, and miR-126-3p, were notably associated with overall survival $[9,70,106-110]$. High expression levels of miR-31 and miR-21 were associated with poor prognosis, but better and prolonged survival was linked with elevated expression of miR-126, miR-708, miR30a, and miR-451 in NSCLC patients [109,110]. The expression analysis and miRNA-hub gene network identified EGFR, phosphatase tensin homolog (PTEN), STAT3, vascular endothelial growth factor-A (VEGFA), transforming protein RhoA (RHOA), catenin beta 1 (CTNNB1), T53, and KRAS as possible target genes for these six miRNAs $[9,70,106-108]$.

MiRNAs can modulate genes and pathways involved in lung tumorigenesis. It was reported that circulating a 3-miRNA signature, including miR-92a-3p, miR-16-5p, and miR-451a, had a high sensitivity $(84 \%)$ and specificity $(100 \%)$ to predict LADC and LSCC $[27,106,111-114]$. These miRNAs are expected to modulate EGFR, K-RAS, and PI3K/AKT signaling, implying that the 3-miRNA signature is biologically significant in LADC and LSCC [27]. Further, the correlation between a novel lncRNA (long noncoding RNA), TRPM2-AS, and the miR-138-5p/EGFR axis was investigated in NSCLC development. TRPM2-AS upregulation in NSCLC tumors and cell lines was validated and associated with induced cellular migration, proliferation, and invasion, as well as inhibiting cell apoptosis; TRPM2-AS was positively associated with EGFR but inversely correlated with miR-138-5p. PI3K/AKT/mTOR axis was stimulated by plasmid cloning DNA (pcDNA)-EGFR but deactivated by miR-138-5p mimics [115-118]. The downregulation of miR-542-5p was inversely correlated with EGFR protein expression, increased vascular invasion, advanced TNM stage, lymphatic metastasis, and poor prognosis in NSCLC (LADC and LSCC). In a CAM (chick chorioallantoic membrane) model, miR-542-5p mimic significantly reduced tumor growth and angiogenesis. The same study, using bioinformatics methods, revealed 457 potential target genes of miR-542-5p as crucial players in cancer-related pathways, such as the cAMP signaling pathway and morphine addiction, of which six overexpressed genes, including PDE4B, GABBR1, PDE4C, ADCY1, ADCY6, and GIPR from the cAMP signaling pathway in NSCLCs tissues [67,119-122]. Overall, these data showed that miRNA-regulated EGFR could differentially affect tumor growth, proliferation, invasion, and metastasis.

\subsection{Effect of EGFR Activation on miRNA Expression}

EGFR hyperactivation, common in lung cancers with poor prognoses, governs miRNA expression, mediates distinct gene regulatory pathways (Table 1). The correlation between EGFR activation and miR-145 expression in normal human lung epithelia cell line (BEAS2B), LADC cell lines with wild-type EGFR (A549 and H292), and with mutant EGFR (H1975 and H1650) was investigated, where miR-145 levels were found to be strongly correlated with p-EGFR. EGF suppressed the expression of miR-145, particularly in BEAS2B and A549 cells [7,83,84,123]. After inhibiting p-EGFR with AG1478, miR-145 was up-regulated, and treatment with AG1478 increased miR-145 by $67.5 \%$ in $\mathrm{H} 1975$ cells. Further, p-EGFR activated the ERK1/2 signaling pathway, and U0126 (ERK1/2 inhibitor) reversed the downregulation of miR-145 caused by EGFR activation [7,83,84]. Likewise, miR-134 suppressed EGFR-associated signaling by down-regulating p-EGFR in A549, H520 H1299, and H1975 cells. However, the down-regulation of p-Akt, p-STAT3, and p-ERK1/2 was not as concordant as predicted. H1299 cells showed decreased p-Akt 
and p-STAT3 but had no significant effect on p-ERK1/2; A549 cells showed decreased p-ERK1/2 and p-Akt but increased p-STAT3; H1975 cells exhibited increased p-STAT3 but decreased p-ERK1/2, whereas no significant changes in p-Akt; H520 cells showed decreased p-Akt, p-STAT3, and p-ERK1/2 [36,55,56]. Furthermore, overexpression of miR134 inhibited EGFR-related signaling and reduced NSCLC cell proliferation by inducing apoptosis and/or cell cycle arrest, inferring that miR-134 acts as an oncosuppressor in NSCLC. The further mechanistic investigation, including rescue experiments and RNAi, indicated the downregulation of EGFR by miR-134 due to the anti-proliferative effect of miR-134. Moreover, in vivo experiments showed that miR-134 suppressed tumor growth of A549 xenograft in nude mice [36,55,56,124]. Immunoblotting showed that EGFR protein levels were also significantly downregulated with miR-7 downregulation [82,125-128].

Being expressed in T cells, B cells, macrophages, dendritic cells, and mesenchymal stem cells, programmed death ligand-1 (PD-L1 or B7-H1 or CD274) plays a key role in immune tolerance in tumors [129-133]. Previously, it was revealed that EGFR activation is due to PD-L1 overexpression in lung cancers, and PD-L1 expression level can be reduced by EGFR-TKIs [134-138]. Recently, the overexpression of miR-155-5p in LADC A549 cells was reported to suppress mRNA expression, membrane protein, and total protein levels of PD-L1 and significantly reduce IFN-c-induced PD-L1 expression [130,134,135,138,139]. These data indicate that miRNA can regulate EGFR indirectly to control inflammation and the immune response in lung cancer (Figure 2). Transfection of NSCLC cells with miR146a mimic resulted in decreased EGFR protein levels and downstream signaling (ERK, AKT, and stat pathways) and these effects were reversed by miR-146a inhibitor treatment. Also, miR-146a induced cellular apoptosis, inhibited cell growth, and suppressed EGFR downstream signaling in NSCLC cell lines (H358, H1975, H1650, HCC827, and H292). MiR$146 \mathrm{a}$ also suppressed these NSCLC cells' migration. These miR-146a-dependent effects are due to its targeting of NF- $\mathrm{BB}$ and EGFR signalings [85-87,140-142].

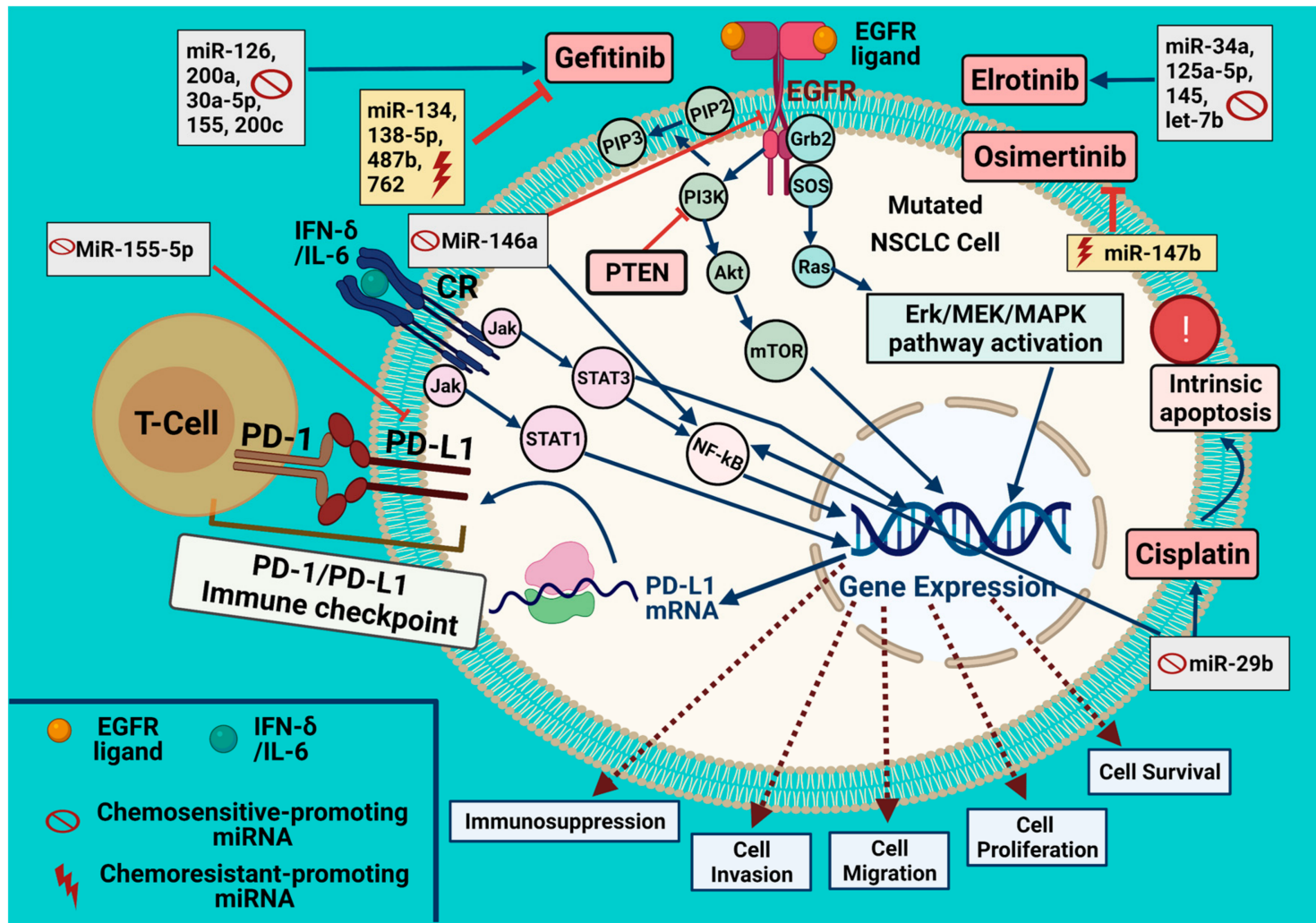

Figure 2. Role of miRNAs in modulating chemosensitivity to EGFR-TKIs and cisplatin in mutated NSCLC cells. In NSCLC tumor cells, EGFR activation results in activating Erk/MEK/MAPK, Akt/mTOR, and Jak/STAT signaling pathways. Cytokines (e.g., IFN-gamma and IL-6) bind to their respective cytokine receptors (CRs), leading to its activation. The NSCLC 
cell chemoresistance to gefitinib increases by miR-134, miR-138-5p, miR-487b, and miR-762 but decreases by miR-126, miR-200a, miR-30a-5p, miR-155, and miR-200c. The cell chemosensitivity to erlotinib was enhanced by miR-34a, miR-125a$5 \mathrm{p}, \mathrm{miR}-145$, and let-7b, yet it decreased to osimertinib by miR-147b. PD-L1 expression can be induced by aberrations in signal transduction components (constitutive expression) and/or many inflammatory cytokines (inducible expression); its expression results in its recruitment at the cell surface and binds to PD-1 on T-cell to avoid immune destruction. MiR-155-5p suppresses mRNA expression, membrane protein, and total protein levels of PD-L1. MiR-146a targets EGFR and NF- $k B$ signaling and significantly suppresses cell proliferation via EGFR-TKI (erlotinib, gefitinib, and afatinib). MiR-29b restored NF- $\mathrm{KB}$ and extrinsic apoptosis. Cisplatin induces intrinsic apoptosis and can be repressed by miR-29b. Blue and red arrows denote for stimulation; dashed brown arrows for cellular effect and red " $\mathrm{T}$ " sign for inhibition.

\section{Specific miRNA Expression Patterns Affect the Behavior of EGFR-Mutated NSCLC}

Emerging evidence indicated that miRNA-mRNA interactions regulate oncogenic processes involved in lung cancer in different ways depending on driver mutations in the tumor $[31,33,35]$. In NSCLC, somatic mutations in the TK domain of EGFR cause its constitutive activation along with its downstream signaling molecules through phosph-Akt even in the absence of ligand, leading to sustained proliferation, invasion and metastasis [143]. Upon tyrosine phosphorylation of the EGFR, recruitment of various signaling proteins, including the Nck (Nck Adaptor Protein), and Adaptor proteins GRB2 (Growth Factor Receptor-Bound Protein-2), SHC (Src Homology-2 Domain Containing Transforming Protein), PLC- $\gamma$ (Phospholipase-C- $\gamma$ ), and STATs (Signal Transducer and Activator of Transcription) occurs [17,143-150]. EGFR mutation is a potent indicator of EGFR-TKIs efficiency in advanced NSCLC therapy, yet about 20-30\% of EGFR-mutated cases exhibited no response to EGFR-TKIs, suggesting the presence of other factors independent of EGFR mutation [80,151-153]. The role of miRNAs (Table 1) in initial resistance to EGFR-TKIs in NSCLC with EGFR mutation is still mysterious. An integrative analysis showed the expression profile of miRNA-mRNA regulatory network in EGFR-mutated LADC using microarray for 155 LADC tissue specimens, where distinct 19 miRNA/431 mRNA signatures, with 5 miRNAs (miR-532-3p, miR-224-5p, miR-500a-3p, miR-532-5p, and miR-502-3p) were discovered as specific miRNAs for EGFR-mutated LADC [154]. The same study indicated 63 putative miRNA-mRNA interactions were potentially involved in EGFR-mutated tumor, including DUSP4 and MUC4 axes in EGFR-mutated LADC [154]. MiR-21 showed more dramatic expression changes in EGFR-mutated patient mutations as opposed to cases with EGFR-wild-type. In lung carcinoma cell lines, a strong association between p-EGFR and miR-21 levels and the suppression of miR-21 by the EGFR-TKI AG1478 indicates that EGFR signaling positively controls miR-21 expression. Antisense inhibition of miR-21 improved AG1478-induced apoptosis in the never-smoker-derived LADC cell line H3255, which had mutant EGFR and elevated levels of p-EGFR and miR-21. These findings indicate that abnormally elevated miR-21 expression, which is further enhanced by an active EGFR signaling system, plays a significant role in lung carcinogenesis and appears to be a possible therapeutic target in EGFR-mutant patients [86,155-160].

A large body of evidence has indicated the robust diagnostic accuracy of miRNAs in patients with mutated-EGFR versus wild-type EGFR. In accordance, the receiver operating curve unveiled the potential diagnostic value (AUC $=0.81, p<0.0001$ ) of circulating miR504 in characterizing patients of EGFR exon 19 deletions from wild-type EGFR normalized to miR-191 [161]. Also, using a miRNA array profiling analysis, T790M/L858R-mutated lung cancer was found to have 20 up-regulated miRNAs, including miR-1 and miR-196a, compared to EGFR wild-type lung cancer [162]. Moreover, using Agilent microarrays, microRNA expression patterns were examined in 154 surgically resected LADC, and 20 matched normal lung tissue samples. Interestingly, 17 miRNAs were differentially expressed between EGFR-mutated and EGFR wild-type tumors, and 129 miRNAs were significantly differentially expressed in LADC compared with normal lung tissue [163]. In addition, miR-218 can negatively regulate EGFR, leading to decreased levels of $\mathrm{p}$ STAT3 [164]. Besides, the downregulation of EGFR reduced the levels of p-STAT3 as well as cell viability more significantly in EGFR-mutated cells (H1975) than in EGFR-wild-type cells (A549) [165]. In addition, 12 miRNAs were substantially more or less abundant in EGFR- 
mutant patients, according to a class comparison study of miRNA expression between 6 EGFR-mutant cases and 22 EGFR-wild-type. MiRNAs (miR-21, miR-210, miR-486,miR-126, miR-126*, miR-138, miR-521, miR-451, miR-30d, and miR-30a) were altered in the same direction in cancer compared to non-neoplastic tissues, implying that EGFR mutations may reinforce the aberrant regulation of some miRNAs linked to lung carcinogenesis in never-smokers. MiR-21 (up-regulated) and miR-486 (down-regulated) were remarkable in malignant vs. non-cancerous tissues between EGFR-mutant and wild-type tumors [155]. Furthermore, a microarray study by Pak et al. investigated three alternately expressed miRNAs, including the tumor suppressor miR-34c, and oncogenes miR-183, and miR-210 in wild type and EGFR-mutated LADC (in exons 19 and 21), where miR-183 expression was notably higher in EGFR-mutated tissues than in wild-type tissues and positively correlated with lymphovascular invasion. Furthermore, the overexpression of miR-34c is associated with poor overall survival in EGFR-mutated (exon 19) group [25]. A 5-miRNA signature has been identified as predictive markers for EGFR mutation in NSCLC, namely miR-25, miR-122, miR-195, miR-21, and miR-125b in tumor tissues and plasma, where plasma levels of has-miR-125b expression in the patients were linked to disease-free survival, and overall survival, thereby acting as a prognostic marker [69]. Further, hsa-miR-126-3p, hsa-miR-21, hsa-miR-145, hsa-miR-183, hsa-miR-182, and hsa-miR-210 were found to be the most differentially expressed miRNAs in lung carcinoma tissues as compared to the adjacent normal lung parenchyma. Most intriguingly, after transfection of hsa-pre-miR-145, an apparent inhibition of cell growth was observed in the EGFR-mutant LADC [7,123].

In LADC tissues, a unique expression pattern of miRNAs was profiled for diverse oncogenic mutations such as KRAS-positive, EGFR-positive, and EGFR/KRAS-negative, in which miR-328, miR-20a, miR-18b, and miR-34c expression levels were highly up-regulated, while miR-32, miR-342, and miR-137 were downregulated [166]. miR-25, miR-155, and miR-495 were overexpressed in EGFR-positive, EGFR/KRAS-negative, and KRAS-positive LADCs groups, respectively. However, let-7g was down-expressed in all three groups, especially in EGFR/KRAS-negative LADC [166]. Kim et al. explored that miR-124, miR-1, and miR-196a were overexpressed in patients with EGFR T790M mutations and resistant to EGFR-TKI in NSCLC [162]. Diagnostic and prognostic classifiers were developed based on miRNAs expression levels as well as mutational gene status $[155,162,163]$. They showed great potential as potent and economic next-generation tools to enhance and complement current genetic tests. A diagnostic classifier was generated to show how miR-26a-5p, miR504, and miR-1253 expression levels can classify NSCLCs such as mutant EGFR, mutant $K R A S$, or $A L K$-translocated versus mutation-free. Further, a prognostic classifier was developed based on Let-7d-5p and miR-769-5p expression levels that can predict overall survival [21].

\section{Effect of miRNAs on the Chemosensitivity to EGFR-TKIs}

EGFR is frequently activated in a wide range of solid tumors, representing an important therapeutic target $[36,167]$. Several EGFR-TKIs, including but not limited to erlotinib, gefitinib, afatinib, osimertinib, and icotinib showed efficient therapeutic activities in NSCLC patients harboring EGFR mutations [15,19-21,33,41,52,71,73,76,168-173]. Although primary responses to EGFR-TKIs in NSCLC patients have been shown, their effectiveness is frequently restricted by drug resistance development $[10,148,150,174]$. The intrinsic and acquired resistance to EGFR-TKIs might occur through numerous mechanisms, including EGFR T790M mutation, PI3K mutations, HER-2 amplification, MET amplification, and alteration into an SCLC phenotype resulting in the poor clinical outcomes of these agents $[10,77,174]$. Though other mechanisms of acquired resistance are still unclear. In recent years, a growing number of miRNAs have been associated with EGFR-TKI resistance, suggesting that miRNAs might be useful as new targets and predictive biomarkers for anti-EGFR treatment [175-177]. miR-133b could interact specifically with the 3'-UTR of EGFR mRNA as evidenced by bioinformatic analysis and luciferase reporter assay. Functionally, miR-133b transfection revealed a regulatory activity in suppressing EGFR mRNA 
translation. Furthermore, miR-133b transfection could modulate invasion, apoptosis and sensitivity to EGFR-TKI through the EGFR signaling pathways, specifically in EGFRaddicted NSCLC cells [178]. An in vitro study revealed that miR-1 significantly inhibited the EGFR-TKI effect, induced cytokines, including C-X-C motif chemokine ligand 10 and $\mathrm{C}-\mathrm{C}$ motif chemokine ligand 5, leading to suppression of monocyte migration. These results indicate that the upregulated miR-1 might suppress the tumor immune microenvironment after developing EGFR-TKI resistance indicating miR-1 as a clinically useful marker to predict the therapeutic efficiency of immunotherapy in LADC patients with EGFR-TKI resistance [179]. MiR-200c-3p participates in EGFR-TKIs sensitivity by modifying the EMT process [74]. In A549 cells, miR-144-5p and miR-497-3p were linked with the signaling pathway of IGF-1R, where they increased the resistance to EGFR-TKIs [168]. Numerous studies emphasized the therapeutic potential of EGFR-regulated miR-21 [69,80,155]. EGFR signaling positively regulates miR-21 expression in lung carcinoma cell lines since the down-expression of miR-21 was induced by an EGFR-TKI [155]. The relationship between miR-21 expression with the acquired resistance to EGFR-TKIs was revealed in NSCLC cell lines, animal models, and advanced NSCLC patients [78,155,156,180,181]. A recent study indicated that the expression levels of miR-21 and Pten are negatively correlated in carcinoma tissues as compared to their matched normal tissues [180]. Further, a positive correlation was found between high miR-21/low PTEN expression levels and high TKI resistance with short overall survival in NSCLC patients undergoing TKI treatment. Thus, the change in miR-21-PTEN expression modulates TKI sensitivity in lung cancer cells $[78,79]$.

The downstream signaling molecules of the EGFR pathway were investigated for their mRNA:miRNA associations, where PIK3R2 with miR-30a-5p, PLCG1 with miR-34a, JAK1 with miR-520e and miR-302b, and GRB2 with miR-27a can be considered as potential drug candidates for treating acquired drug resistance in NSCLCs [15]. Other RTK pathways are shared with the EGFR signaling pathway, including PDGFR, IGF-1R, c-MET, and Ron [15,57-60]. MiR-30a-5p directly targeting CD73 was downregulated in NSCLC, and that miR-30a-5p overexpression in NSCLC cell lines suppressed in vitro and in vivo cell proliferation, migration, invasion, and EMT phenotype via EGF signaling [70]. Thus, CD73 can affect the efficiency of EGFR-targeted therapies via miR-30a-5p in wild-type EGFR in NSCLC cells; yet, further studies are still needed to explore the underlying mechanisms of CD73-mediated drug resistance to improve the NSCLC treatment [70]. A negative correlation was observed between the expression levels of miR-449a and nicotinamide $\mathrm{N}$-methyltransferase (NNMT), a metabolic enzyme linked to cancer, in EGFR-TKI-resistant NSCLC models. In addition, NNMT knockdown inhibited p-Akt and tumorigenesis, but reexpression of miR-449a induced PTEN and suppressed tumor growth [182]. Interestingly, the differential expression of 12 miRNAs between the EGFR-TKI-resistant and sensitive groups was identified, whose aberrant expressions are linked to lung tumorigenesis, drug resistance, and EGFR pathway regulation for patients with EGFR 19 deletion mutations [80]. Of these 12 miRNAs, miR-27a, miR-21, and miR-218 were confirmed to be overexpressed in the resistant group related to the sensitive group [80]. In addition, expression analysis of plasma miRNAs (76 up-regulated and 3 downregulated) was performed in NSCLC patients with del19 or L858R EGFR mutation [183]. Moreover, the overexpression of miR-222 and miR-155 was associated with poor prognoses, positive EGFR mutation, and metastasis in late-stage NSCLC, and that overexpression of miR-34 represents a biomarker for LADC cell type, multiple metastases, and LADC negative EGFR mutation [184]. Furthermore, miR-184 and miR-197 were up-regulated in LADC tumor tissue patients, who harbor EGFR mutations with brain metastasis, indicating these miRNAs as novel biomarkers differentiating the risk of brain metastasis [185]. Many studies demonstrate the role of miRNA in modulating cell sensitivity to erlotinib, gefitinib, osimertinib, afatinib, and icotinib [71,72,169,175,186,187]. 


\subsection{Erlotinib}

Erlotinib (Tarceva ${ }^{\circledR}$ ) is an EGFR-TKI [188]. Although various mechanisms that drive resistance to EGFR-inhibitors have been identified, many cases have unclear mechanisms. Many research studies pointed out the implication of numerous miRNAs in modulating NSCLC sensitivity to erlotinib $[20,57-60,83,84,169,186]$. An exciting study by Gober et al. predicted a 13-miRNA signature for the response to the EGFR-TKI erlotinib in NSCLC cell lines and tumors and discriminated primarily from metastatic tumors [72,185,186,189]. For example, the ectopic expression of miR-200c changed sensitivity to erlotinib, EMT proteins expression, invasion, and metastasis in lung cells [186]. The EMT transcription factor, ZEB1, reveals altered expression in erlotinib-sensitive NSCLC, where many miRNA gene signatures are up-regulated. Again, the miR-145 expression significantly inhibited EGFR expression and improved the sensitivity to erlotinib. Thus, miR-145 plays a critical role in EGFR-TKIs resistance, cell proliferation, and survival [71]. Furthermore, the expression of EGFR mRNA was significantly reduced by miR-125a-5p (down-regulated in lung cancer) and consequently inhibited cell proliferation and efficiently triggered apoptosis [72]. Besides, the synergistic pretreatment with miR-125a-5p augmented the cytotoxic effect of erlotinib by reducing cellular proliferation, and enhanced the apoptotic effect, thus bypassing the resistance to EGFR-TKIs in lung cancer cells [72]. In KRAS- and TP53- mutant NSCLC, the treatment with miR-34a and let-7b (oncosuppressor), individually or in combination, lead to a synergistic potentiation of erlotinib's anti-proliferative activity. These miRNAs could target oncogenic pathways beyond those inhibited by EGFR. Further, combinatorial treatment with miR-34a and let-7b caused the strongest synergy with erlotinib, suggesting that these miRNAs can efficiently target multiple cellular pathways involved in cellular proliferation and cell resistance to erlotinib [20,57-60,169]. Again, a significant synergistic interaction between miR-34a mimics and erlotinib was revealed in NSCLC cells either with primary or acquired erlotinib resistance that indicated miR-34a-centered therapy could be used to increase EGFR-TKI sensitivity $[57-60,169]$. Further, pretreatment with miR-145 improved lung cancer cells' sensitivity to erlotinib synergistically. miR-145 could induce apoptosis and increase erlotinib levels in A549 NSCLC cells. The pretreatment with miR-145 reduced tumor growth by suppressing the expression of EGFR induced cell arrest of the G1/S cycle phase, and improved the sensitivity of A549, NSCLC cell line, to erlotinib $[7,83,84]$.

Recently, the detection of miR-133b expression levels is associated with a better prognosis and identifies NSCLC patients who are expected to benefit from second and thirdline therapy with erlotinib. miR-133b expression levels can be used to differentiate nonresponder from responder patients to erlotinib, where the overexpression of miR-133b was associated with longer progression-free survival time of NSCLCs patients. miR-133b mimic transfection in A549 and H1299 NSCLC cell lines revealed that the decreased cell growth and altered morphology were due to higher expression of miR-133b, yet it did not affect sensitivity to erlotinib [190]. In functional experiments, miR-146a inhibited EGFR downstream signaling, repressed cell growth, promoted cellular apoptosis, and suppressed the migratory capacity in different NSCLC cell lines (H358, H1650, H1975, HCC827, and H292). Moreover, miR-146a improved the inhibition of cell proliferation upon treatment with EGFR-TKIs (erlotinib, gefitinib, and afatinib) as well as a monoclonal antibody (cetuximab). Interestingly, these effects were independent of the EGFR mutation status (wild type, resistance mutation, or sensitizing mutation). Hence, miR-146a is a strong prognostic biomarker and therapeutic candidate in NSCLC [85-87]. qRT-PCR assay unveiled higher miR-214 expression in the acquired erlotinib-resistant HCC827 (HCC827/ER) cells than in HCC827 cells and in NSCLC patients' plasma with acquired EGFR-TKI resistance compared to those before exposure to EGFR-TKI therapy. LIM Homeobox 6 (LHX6) is a direct target gene of miR-214, and LHX6 expression was detected to be down-regulated in HCC827/ER cells. In transwell invasion assay, LHX6 overexpression reversed the increase in HCC827 cells' invasive capacity induced by miR-214 overexpression, and the CRISPR-Cas9 system-mediated LHX6 knockdown inverse the reduced invasion 
of HCC827/ER cells caused by miR-214 down-regulation [173]. miR-506-3p expression was significantly reduced in erlotinib-resistant cells, in which Sonic Hedgehog (SHH), a novel target of miR-506-3p, is aberrantly activated. The ectopic miR-506-3p expression in erlotinib-resistant cells downregulated SHH signaling, inhibited vimentin expression, increased E-cadherin expression, thereby reducing EMT-mediated chemoresistance. This indicates that the miR-506/SHH axis might signify a novel therapeutic target for future EGFR-mutated NSCLC [191]. miR-641 overexpression was observed in human NSCLC samples and NSCLC cells with resistance to TKI than those sensitive to TKI, and this overexpression induced TKI resistance in NSCLC cells. Interestingly, miR-641 activates ERK signaling in NSCLC cells by directly targeting neurofibromatosis 1 (NF1), where NF1 overexpression or ERK silencing could block miR-641-induced NSCLC cell resistance to erlotinib treatment. In animal model experiments, the combination of miR-641 inhibition and erlotinib treatment showed significant inhibition of erlotinib-resistant-NSCLC growth, suppressed proliferation, and induced apoptosis compared to monotherapy [192,193]. This suggests that increased expression of miR-641 significantly contributes to erlotinib resistance development in NSCLC cells through activating ERK signaling by targeting NF1 and that inhibition of miR-641 may reverse the acquired resistance of NSCLC cells to erlotinib treatment [193].

Both primary (EGFR wild-type) and acquired resistance to EGFR-TKIs in NSCLC cells can be overcome by combined treatment with miR-34a [58,60,62,63,194]. For T790M mutants, the synergy effects may exert through miR-34a-dependent repression of AXL or MET, major mediators of erlotinib resistance, or their respective ligands, that contribute to delay resistance in EGFR-mutated HCC827-RC2 cells, which lack the secondary T790M mutation [195-198].

\subsection{Gefitinib}

Gefitinib (Iressa) is an EGFR-TKI that inhibits the TK activity by competitively blocking the ATP binding site. In preclinical studies, gefitinib has shown a potent activity in many tumor models, including several lung cancer cell lines and xenografts [199-203]. Emerging evidence indicates that various miRNAs could modulate tumor progression in response to gefitinib therapy $[78,175,204-210]$. The EGFR-independent activity of the PI3Ks/Akt or Ras/ERK pathway contributes to gefitinib-resistance in NSCLC cell lines. Besides, the anti-EGFR treatment in combination with particular inhibitors of these pathways may result in further cytotoxic effects in NSCLC cell lines [204]. The expression levels of miR-155 and miR-200c were reduced in HCC 827 cells treated with gefitinib treatment. The decrease of miR-155 and miR-200c levels might be linked with either histone modifications and the EMT or the gefitinib sensitivity reduction independent of EGFR mutation [175,205-207]. Notably, miR-200a is downregulated and directly targets EGFR and $c$-Met mRNAs in NSCLC cells. Interestingly, miR-200a overexpression downregulates EGFR and $c$-Met levels and effectively inhibits invasion, migration, and gefitinib resistance in NSCLC cells [1,208-211]. MiR-30a-5p can target EGFR and IGF-1R signaling pathways, and its overexpression could regulate PI3K/AKT signaling pathway to promote cell apoptosis, impede cell migration and invasion properties, and attenuate the EGFR-inhibitor gefitinib resistance in NSCLC cell lines [15,73]. Additionally, the upregulation of miR-762 in NSCLC tissues and cells showed gefitinib resistance, indicating post chemotherapy's poor prognosis. Notably, IL-6 signaling-induced miR-762 upregulation improved cell survival and retained NSCLC cell resistance to gefitinib [75]. Besides, the oncogenic effect of miR762 was mediated mostly via post-transcriptional repression of ABR in gefitinib-resistant NSCLC cells [75]. In H460 and A549 cells, miR-126 restoration significantly suppressed cell growth in both cells, where the inhibition of Akt and ERK activation inhibited cell proliferation [19]. Furthermore, the overexpression of miR-126 enhanced gefitinib-induced cytotoxicity in lung cancer cells [19,212-214].

MiRNA microarray screening showed the significant downregulation of miR-138-5p in PC9GR cells, yet its re-expression increased the sensitivity to gefitinib in gefitinib-resistant 
NSCLC cell lines (H1975 and PC9GR) [76]. Further, miR-138-5p expression was reduced in gefitinib-resistant cells relative to sensitive cells. Additionally, a luciferase reporter assay and bioinformatics analysis revealed a direct target of miR-138-5p, namely GPR124, whose expression was repressed on mRNA and protein levels in NSCLC cells and LADC specimens, increasing their gefitinib-associated sensitivity $[76,215,216]$. Again, miR-134 and miR-487b overexpression altered the resistance to gefitinib and induced the EMT phenomenon, yet these miRNAs knockdown increased sensitivity to gefitinib via TGF $\beta 1$ and suppressed the EMT process [124]. The cluster of miR-134/miR-487b/miR-655 showed the aforementioned effects through direct targeting of MAGI2, leading to a loss of PTEN stability in NSCLC resistant to EGFR-TKI $[9,78,124,217,218]$. Overall, these data show that miRNAs can modulate the EGFR-TKI effect by increasing their sensitivity or resistance depending on EGFR and EGFR-activated downstream signaling molecules (Figure 2).

miR-17 family expression was upregulated, while let-7 family expression was downregulated in PC9/GR cells relative to gefitinib-sensitive PC9 cells that promoted gefitinib resistance via regulating the self-renewal ability of NSCLC cells. Importantly, miR-17 participated in cell cycle regulation by controlling its target gene cyclin-dependent kinase inhibitor 1A (CDKN1A), to sustain the proliferative potential. However, let-7 maintained stem cell characteristics by regulating the target gene MYC to retain the undifferentiated status [219]. Of note, dual inhibitors of IGF1R and EGFR markedly decreased p-AKT and p-ERK expression levels compared with the control group in H1650GR (H1650-acquired gefitinib-resistance), H460, and $\mathrm{H} 1975$ cell lines. miR-30a-5p mimics, along with repressing PI3K expression, can induce cell apoptosis, suppress cell invasion and migration in the treated H1650GR cell line [220-224]. Compared to gefitinib-sensitive cell line PC9, miR-133a-3p was significantly downregulated in PC9/GR cell line, and miR-133a-3p overexpression increased the NSCLC cells' sensitivity to gefitinib and vice versa. Moreover, sperm-associated antigen 5 (SPAG5), an important target gene of miR-133a-3p, reversed the miR-133a-3p-mediated sensitivity of NSCLC cells to gefitinib, implying that the miR-133a3p/SPAG5 axis played a key role in acquired resistance to gefitinib in NSCLC cells [225]. In EGFR-mutant NSCLC models with acquired gefitinib resistance, miR-483-3p mimics efficiently improved sensitivity of gefitinib-resistant NSCLC cells to gefitinib by suppressing proliferation and promoting apoptosis. Also, miR-483-3p reversed EMT and repressed migration, invasion, and metastasis of GR NSCLC cells. Mechanistically, miR-483-3p directly targeted integrin $\beta 3$, consequently inhibiting the downstream FAK/Erk signaling pathway, highlighting miR-483-3p is a prospective target for combination treatment to overcome acquired EGFR TKI resistance in EGFR-mutant NSCLC [226,227]. miR-625-3p can potentially target AXL receptor tyrosine kinase, and this miRNA expression is markedly decreased in the HCC827GR cell line, while its overexpression partly reversed gefitinib resistance. Mechanistic analysis indicated that TGF- $\beta 1$-induced EMT might contribute to the miR-625-3p/AXL signaling that mediated gefitinib resistance [228].

\subsection{Other EGFR-TKI}

Clinical analysis revealed a significantly higher miR-146b-5p expression in pleural effusions-isolated lung cancer cells from treatment-naive patients than acquiring resistance patients to EGFR-TKI treatment [172,229-232]. Further, ectopic expression of miR-146b-5p improved EGFR-TKI-induced apoptosis in EGFR-TKI-resistant cells, EGFR-independent and -dependent osimertinib-resistant primary cancer cells (PE2988 and PE3479). In rescue experiments, miR-146b-5p target IRAK1 and in turn, repressed NF- $\mathrm{kB}$ activity and NF- $\kappa B$-related IL-6 and IL-8 production. Thus, miR-146b-5p/IRAK1/NF- $\mathrm{kB}$ signaling promotes EGFR-TKI resistance [172]. EMT phenomenon was indicated in HCC827-OR and PC-9-OR cells. Microarray and qRT-PCR analyses unveiled the co-upregulated miR210-3p in exosomes isolated from HCC827-OR and PC-9-OR cells relative to those isolated from parental HCC827 and PC-9 cells. HCC827-OR cell-derived exosomes provoked EMT changes and osimertinib resistance in HCC827 cells. As a result, miR-210-3p induction directly mediated the EMT phenomenon and resistance to osimertinib in HCC827 
cells $[170,233-237]$. Using the GEO database to analyze miRNA array data and the interaction networks, miR-184, miR-30d-3p, miR-542-3p, and miR-500a were shown to suppress EGFR-TKI, confirming their chemo-resistant mechanism [122]. A reversible tolerant state to osimertinib, an EGFR inhibitor, was driven by miR-147b, the foremost overexpressed miRNA in both EGFR-mutated and osimertinib-tolerant lung cancer cells, by suppressing succinate dehydrogenase and VHL that linked to the pseudohypoxia and tricarboxylic acid cycle (TCA) pathways [77]. Using the differential lncRNA expression and transcriptome sequencing analyses, APCDD1L-AS1, a novel lncRNA, was the most upregulated lncRNA in icotinib-resistant LAD cells promoted icotinib resistance and upregulated the EGFR protein expression level by sponging with $\mathrm{miR}-1322 / \mathrm{miR}-1972 / \mathrm{miR}-324-3 \mathrm{p}$ to remove the transcription inhibition of SIRT5 [238,239]. Moreover, SIRT5 increased EGFR expression and activation by suppressing EGFR autophagic degradation, thus promoting icotinib resistance. Consistently, the autophagy initiator rapamycin could decrease EGFR levels and enhance the sensitivity of icotinib-resistant LAD cells to icotinib [171].

\section{Conclusions}

Collectively, the EGFR signaling pathway and dysregulated miRNA expression pattern are key players in NSCLC development and treatment response. MiRNA-EGFR crosstalk can induce or suppress tumor growth based on the expressed miRNAs' oncogenic or tumor-suppressive functions. The signature of miRNA/EGFR expression or miRNAEGFR interactions can be utilized as diagnostic, prognostic, and therapeutic biomarkers in NSCLCs. Therefore, the miRNA-EGFR regulatory network can control many cellular processes. miRNA-dependent EGFR expression and/or hyperactivation have been associated with lung cancer cell behavior, including cell survival, resisting cell apoptosis, cell migration and invasion, proliferative activity, and modulating cell sensitivity to TKIs. However, these cellular processes are cell-context-dependent, e.g., NSCLC subtypes (LADC, LSCC, or LLCC). Interestingly, the use of EGFR-TKIs has considerably improved the prognosis of NSCLC patients harboring EGFR mutations. However, drug resistance development, either de novo or acquired, restrains the EGFR-TKI efficacy for prolonged usage (no longer than one year). Thus, these patients show enhanced disease progression and shorter survival. Furthermore, in a few EGFR-mutated NSCLC cases, the intrinsic mechanisms of drug resistance that exist before TKI drug treatment preclude its clinical benefit. The exploration of miRNA-dependent EGFR signaling that affects lung cancer cell behavior will essentially improve the design of a therapeutic modality for NSCLC. The integration of lung cancer screening algorithms into miRNA-dependent EGFR expression may be a useful tool for improving the screening specificity and lowering the mortality rate associated with lung cancer. Moreover, identifying potential predictors for the response to EGFR-TKIs therapies will contribute to the selection of patients with NSCLC who benefit from treatment and minimize the side effects of ineffective therapy exposure.

Author Contributions: Conceptualization, S.S.H., and S.A.I.; literature searches, S.S.H., S.A.I., and A.L.A.-M.; data curation, S.A.I., S.S.H., and A.L.A.-M.; supervision, A.L.A.-M., and S.A.I.; figures design, S.S.H.; writing—original draft, S.S.H., S.A.I., and A.L.A.-M.; writing-review and editing, S.S.H., S.A.I., and A.L.A.-M. This article is based primarily on the student MSc. thesis, S.S.H. All authors have read and agreed to the published version of the manuscript.

Funding: This research received no external funding.

Institutional Review Board Statement: Not applicable.

Informed Consent Statement: Not applicable.

Data Availability Statement: Not applicable.

Acknowledgments: All the figures were created with BioRender.com.

Conflicts of Interest: The authors declare that no conflict of interest (neither financial nor personal) exists. 


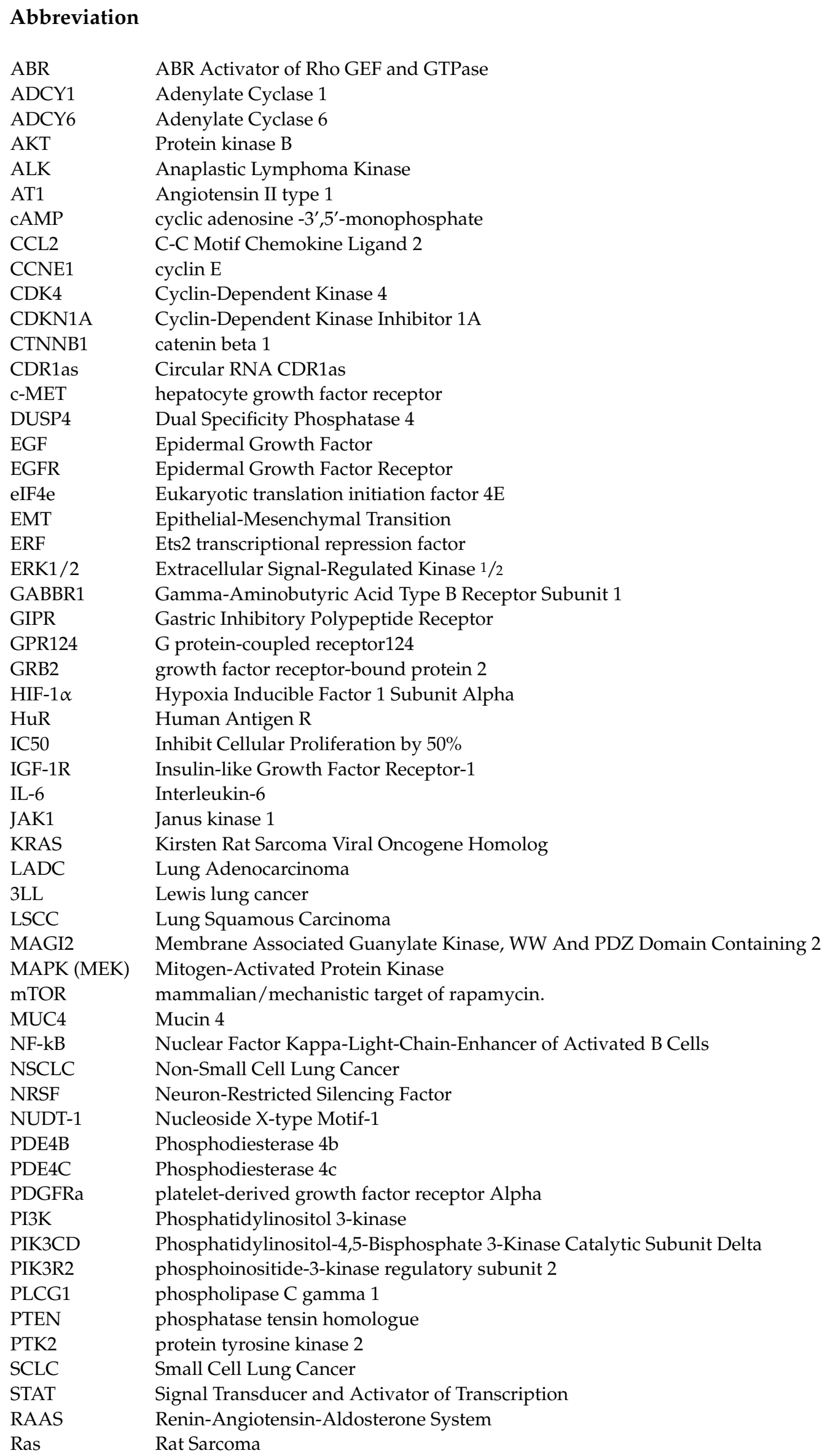




$\begin{array}{ll}\text { Raf } & \text { Rapidly Accelerated Fibrosarcoma } \\ \text { RAF-1 } & \text { Rapidly Accelerated Fibrosarcoma homolog-1 } \\ \text { RHOA } & \text { Transforming protein RhoA } \\ \text { Ron } & \text { a protein tyrosine kinase related to c-MET } \\ \text { RTK } & \text { Receptor Tyrosine Kinase } \\ \text { TCA } & \text { Tricarboxylic Acid Cycle } \\ \text { TGF } \beta & \text { Transforming Growth Factor Beta } \\ \text { TKIs } & \text { Tyrosine Kinase Inhibitors } \\ \text { TNFAIP3 } & \text { Tumor necrosis factor, alpha-induced protein } 3 \text { or A20 } \\ \text { TNM } & \text { Tumor, nodes, and metastasis } \\ \text { TRPM2 } & \text { Transient receptor potential cation channel, subfamily M, member 2 } \\ \text { VEGFA } & \text { Vascular endothelial growth factor-A } \\ \text { VHL } & \text { Von Hippel-Lindau disease } \\ \text { ZEB1 } & \text { zinc finger E-box binding homeobox 1 }\end{array}$

\section{References}

1. Zhen, Q.; Liu, J.; Gao, L.; Liu, J.; Wang, R.; Chu, W.; Zhang, Y.; Tan, G.; Zhao, X.; Lv, B. MicroRNA-200a Targets EGFR and c-Met to Inhibit Migration, Invasion, and Gefitinib Resistance in Non-Small Cell Lung Cancer. Cytogenet. Genome Res. 2015, 146, 1-8. [CrossRef]

2. MacDonagh, L.; Gray, S.G.; Finn, S.P.; Cuffe, S.; O’Byrne, K.J.; Barr, M.P. The emerging role of microRNAs in resistance to lung cancer treatments. Cancer Treat. Rev. 2015, 41, 160-169. [CrossRef]

3. Garinet, S.; Laurent-Puig, P.; Blons, H.; Oudart, J.-B. Current and Future Molecular Testing in NSCLC, What Can We Expect from New Sequencing Technologies? J. Clin. Med. 2018, 7, 144. [CrossRef]

4. Wang, F.; Chan, L.W.C.; Law, H.K.W.; Cho, W.C.S.; Tang, P.; Yu, J.; Shyu, C.R.; Wong, S.C.C.; Yip, S.P.; Yung, B.Y.M. Exploring microRNA-mediated alteration of EGFR signaling pathway in non-small cell lung cancer using an mRNA: MiRNA regression model supported by target prediction databases. Genomics 2014, 104, 504-511. [CrossRef]

5. Zhang, Y.; Yang, Q.; Wang, S. MicroRNAs: A new key in lung cancer. Cancer Chemother. Pharmacol. 2014, 74, 1105-1111. [CrossRef] [PubMed]

6. Badawy, A.A.; Khedr, G.; Omar, A.; Bae, S.; Arafat, W.; Grant, S. Site of metastases as prognostic factors in unselected population of stage IV non-small cell lung cancer. Asian Pacific. J. Cancer Prev. 2018, 19, 1907-1910. [CrossRef]

7. Wang, R.J.; Zheng, Y.H.; Wang, P.; Zhang, J.Z. Serum miR-125a-5p, miR-145 and miR-146a as diagnostic biomarkers in non-small cell lung cancer. Int. J. Clin. Exp. Pathol. 2015, 8, 765-771.

8. Souza, C.P.; Cinegaglia, N.C.; Felix, T.F.; Evangelista, A.F.; Oliveira, R.A.; Hasimoto, E.N.; Cataneo, D.C.; Cataneo, A.J.M.; Neto, C.S.; Viana, C.R.; et al. Deregulated microRNAs Are Associated with Patient Survival and Predicted to Target Genes That Modulate Lung Cancer Signaling Pathways. Cancers 2020, 12, 2711. [CrossRef]

9. Song, F.; Xuan, Z.; Yang, X.; Ye, X.; Pan, Z.; Fang, Q. Identification of key microRNAs and hub genes in non-small-cell lung cancer using integrative bioinformatics and functional analyses. J. Cell. Biochem. 2020, 121, 2690-2703. [CrossRef] [PubMed]

10. Kumarakulasinghe, N.B.; van Zanwijk, N.; Soo, R.A. Molecular targeted therapy in the treatment of advanced stage non-small cell lung cancer (NSCLC). Respirology 2015, 20, 370-378. [CrossRef]

11. Hsu, P.C.; Jablons, D.M.; Yang, C.T.; You, L. Epidermal growth factor receptor (EGFR) pathway, yes-associated protein (YAP) and the regulation of programmed death-ligand 1 (PD-L1) in non-small cell lung cancer (NSCLC). Int. J. Mol. Sci. 2019, $20,3821$. [CrossRef]

12. Wang, K.; Park, J.O.; Zhang, M. Treatment of glioblastoma multiforme using a combination of small interfering RNA targeting epidermal growth factor receptor and $\beta$-catenin. J. Gene Med. 2013, 15, 42-50. [CrossRef]

13. Oronsky, B.; Ma, P.; Reid, T.R.; Cabrales, P.; Lybeck, M.; Oronsky, A.; Oronsky, N.; Carter, C.A. Navigating the "No Man's Land” of TKI-Failed EGFR-Mutated Non-Small Cell Lung Cancer (NSCLC): A Review. Neoplasia 2018, 20, 92-98. [CrossRef]

14. Yang, Z.; Tam, K.Y. Combination strategies using EGFR-TKi in NSCLC therapy: Learning from the gap between pre-clinical results and clinical outcomes. Int. J. Biol. Sci. 2018, 14, 204-216. [CrossRef] [PubMed]

15. Wang, F.; Meng, F.; Wang, L.; Wong, S.C.C.; Cho, W.C.S.; Chan, L.W.C. Associations of mRNA:microRNA for the shared downstream molecules of EGFR and alternative tyrosine kinase receptors in non-small cell lung cancer. Front. Genet. 2016, 7, 173. [CrossRef]

16. Lemmon, M.A.; Schlessinger, J. Cell signaling by receptor tyrosine kinases. Cell 2010, 141, 1117-1134. [CrossRef] [PubMed]

17. Vázquez, S.; Anido, U.; Lázaro, M.; Santomé, L.; Afonso, J.; Fernández, O.; Alegría, A.M.D.; Aparicio, L.A. Angiogenesis and Lung Cancer. Oncog. Inflamm. Parasit. Trop. Dis. Lung 2013. [CrossRef]

18. Sigismund, S.; Avanzato, D.; Lanzetti, L.; Lanzetti, L. Emerging functions of the EGFR in cancer. Mol. Oncol. 2017, 12, 3-20. [CrossRef]

19. Zhong, M.; Ma, X.; Sun, C.; Chen, L. MicroRNAs reduce tumor growth and contribute to enhance cytotoxicity induced by gefitinib in non-small cell lung cancer. Chem. Biol. Interact. 2010, 184, 431-438. [CrossRef] [PubMed] 
20. Stahlhut, C.; Slack, F.J. Combinatorial action of MicroRNAs let-7 and miR-34 effectively synergizes with erlotinib to suppress non-small cell lung cancer cell proliferation. Cell Cycle 2015, 14, 2171-2180. [CrossRef]

21. Gasparini, P.; Cascione, L.; Landi, L.; Carasi, S.; Lovat, F.; Tibaldi, C.; Alì, G.; D’Incecco, A.; Minuti, G.; Chella, A.; et al. MicroRNA classifiers are powerful diagnostic/prognostic tools in ALK-, EGFR-, and KRAS-driven lung cancers. Proc. Natl. Acad. Sci. USA 2015, 112, 14924-14929. [CrossRef]

22. Hayes, J.; Peruzzi, P.P.; Lawler, S. MicroRNAs in cancer: Biomarkers, functions and therapy. Trends Mol. Med. 2014, 20, 460-469. [CrossRef] [PubMed]

23. Calin, G.A.; Croce, C.M. MicroRNA signatures in human cancers. Nat. Rev. Cancer 2006, 6, 857-866. [CrossRef]

24. John, B.; Enright, A.J.; Aravin, A.; Tuschl, T.; Sander, C.; Marks, D.S. Human microRNA targets. PLoS Biol. 2004, 2, e363. [CrossRef]

25. Pak, M.G.; Lee, C.H.; Lee, W.J.; Shin, D.H.; Roh, M.S. Unique microRNAs in lung adenocarcinoma groups according to major TKI sensitive EGFR mutation status. Diagn. Pathol. 2015, 10, 99. [CrossRef]

26. Giordano, M.; Boldrini, L.; Servadio, A.; Niccoli, C.; Melfi, F.; Lucchi, M.; Mussi, A.; Fontanini, G. Differential microRNA expression profiles between young and old lung adenocarcinoma patients. Am. J. Transl. Res. 2018, 10, 892-900. [CrossRef] [PubMed]

27. Reis, P.P.; Drigo, S.A.; Carvalho, R.F.; Lapa, R.M.L.; Felix, T.F.; Patel, D.; Cheng, D.; Pintilie, M.; Liu, G.; Tsao, M.S. Circulating miR-16-5p, miR-92a-3p, and miR-451a in plasma from lung cancer patients: Potential application in early detection and a regulatory role in tumorigenesis pathways. Cancers 2020, 12, 1-16. [CrossRef]

28. Leonetti, A.; Assaraf, Y.G.; Veltsista, P.D.; El Hassouni, B.; Tiseo, M.; Giovannetti, E. MicroRNAs as a drug resistance mechanism to targeted therapies in EGFR-mutated NSCLC: Current implications and future directions. Drug Resist. Updat. 2019, 42, 1-11. [CrossRef]

29. Hwang, H.W.; Mendell, J.T. MicroRNAs in cell proliferation, cell death, and tumorigenesis. Br. J. Cancer 2006, 94, 776-780. [CrossRef] [PubMed]

30. Inamura, K.; Ishikawa, Y. MicroRNA In Lung Cancer: Novel Biomarkers and Potential Tools for Treatment. J. Clin. Med. 2016, 5, 36. [CrossRef]

31. Iorio, M.V.; Croce, C.M. MicroRNA dysregulation in cancer: Diagnostics, monitoring and therapeutics. A comprehensive review. EMBO Mol. Med. 2012, 4, 143-159. [CrossRef]

32. Gómez-Gómez, Y.; Organista-Nava, J.; Gariglio, P. Deregulation of the miRNAs Expression in Cervical Cancer: Human Papillomavirus Implications. Biomed. Res. Int. 2013, 2013, 15. [CrossRef]

33. Zhao, X.M.; Liu, K.Q.; Zhu, G.; He, F.; Duval, B.; Richer, J.M.; Huang, D.S.; Jiang, C.J.; Hao, J.K.; Chen, L. Identifying cancer-related microRNAs based on gene expression data. Bioinformatics 2015, 31, 1226-1234. [CrossRef] [PubMed]

34. Kan, Z.; Jaiswal, B.S.; Stinson, J.; Janakiraman, V.; Bhatt, D.; Stern, H.M.; Yue, P.; Haverty, P.M.; Bourgon, R.; Zheng, J.; et al. Diverse somatic mutation patterns and pathway alterations in human cancers. Nature 2010, 466, 869-873. [CrossRef]

35. Garzon, R.; Fabbri, M.; Cimmino, A.; Calin, G.A.; Croce, C.M. MicroRNA expression and function in cancer. Trends Mol. Med. 2006, 12, 580-587. [CrossRef]

36. Qin, Q.; Wei, F.; Zhang, J.; Wang, X.; Li, B. miR-134 inhibits non-small cell lung cancer growth by targeting the epidermal growth factor receptor. J. Cell. Mol. Med. 2016, 20, 1974-1983. [CrossRef] [PubMed]

37. Ahmed, S.H.; Espinoza-Sánchez, N.A.; El-Damen, A.; Fahim, S.A.; Badawy, M.A.; Greve, B.; El-Shinawi, M.; Götte, M.; Ibrahim, S.A. Small extracellular vesicle-encapsulated miR-181b-5p, miR-222-3p and let-7a-5p: Next generation plasma biopsy-based diagnostic biomarkers for inflammatory breast cancer. PLoS ONE 2021, 16, e0250642. [CrossRef]

38. Fahim, S.A.; Abdullah, M.S.; Espinoza-Sánchez, N.A.; Hassan, H.; Ibrahim, A.M.; Ahmed, S.H.; Shakir, G.; Badawy, M.A.; Zakhary, N.I.; Greve, B.; et al. Inflammatory Breast Carcinoma: Elevated microRNA miR-181b-5p and Reduced miR-200b-3p, miR-200c-3p, and miR-203a-3p Expression as Potential Biomarkers with Diagnostic Value. Biomolecules 2020, 10, 1059. [CrossRef] [PubMed]

39. Xiang, Y.; Tian, Q.; Guan, L.; Niu, S.S. The Dual Role of miR-186 in Cancers: Oncomir Battling With Tumor Suppressor miRNA. Front. Oncol. 2020, 10, 233. [CrossRef]

40. Ding, L.; Lan, Z.; Xiong, X.; Ao, H.; Feng, Y.; Gu, H.; Yu, M.; Cui, Q. The Dual Role of MicroRNAs in Colorectal Cancer Progression. Int. J. Mol. Sci. 2018, 19, 2791. [CrossRef]

41. Langsch, S.; Baumgartner, U.; Haemmig, S.; Schlup, O.; Schäfer, S.C.; Berezowska, S.; Rieger, G.; Dorn, P.; Tschan, M.P.; Vassella, E. miR-29b mediates NF-kkB signaling in KRAS-Induced non-small cell lung cancers. Cancer Res. 2016, 76, 4160-4169. [CrossRef]

42. Song, G.; Zhou, Y.; Chen, R.; Li, Q.; Shan, B.; Duan, Y.; Wang, Y. Expression and Function Analysis of MicroRNA-29b in Xuanwei Lung Cancer. Clin. Lab. 2016, 62, 1739-1745. [CrossRef]

43. Yu, D.H.; Ruan, X.-L.; Huang, J.-Y.; Liu, X.-P.; Ma, H.-L.; Chen, C.; Hu, W.-D.; Li, S. Analysis of the Interaction Network of Hub miRNAs-Hub Genes, Being Involved in Idiopathic Pulmonary Fibers and Its Emerging Role in Non-small Cell Lung Cancer. Front. Genet. 2020, 11, 302. [CrossRef] [PubMed]

44. Magalhães, M.; Jorge, J.; Gonçalves, A.C.; Sarmento-Ribeiro, A.B.; Carvalho, R.; Figueiras, A.; Santos, A.C.; Veiga, F. miR-29b and retinoic acid co-delivery: A promising tool to induce a synergistic antitumoral effect in non-small cell lung cancer cells. Drug Deliv. Transl. Res. 2020, 10, 1367-1380. [CrossRef] 
45. Wang, H.; Guan, X.; Tu, Y.; Zheng, S.; Long, J.; Li, S.; Qi, C.; Xie, X.; Zhang, H.; Zhang, Y. MicroRNA-29b attenuates non-small cell lung cancer metastasis by targeting matrix metalloproteinase 2 and PTEN. J. Exp. Clin. Cancer Res. 2015, 34, 59. [CrossRef] [PubMed]

46. Rothschild, S.I.; Tschan, M.P.; Federzoni, E.A.; Jaggi, R.; Fey, M.F.; Gugger, M.; Gautschi, O. MicroRNA-29b is involved in the Src-ID1 signaling pathway and is dysregulated in human lung adenocarcinoma. Oncogene 2012, 31, 4221-4232. [CrossRef] [PubMed]

47. Grandis, J.R.; Sok, J.C. Signaling through the epidermal growth factor receptor during the development of malignancy. Pharmacol. Ther. 2004, 102, 37-46. [CrossRef]

48. Tasdemir, S.; Taheri, S.; Akalin, H.; Kontas, O.; Onal, O.; Ozkul, Y. Increased EGFR mRNA expression levels in non-small cell lung cancer. Eurasian J. Med. 2019, 51, 176-184. [CrossRef] [PubMed]

49. Wang, F.; Cho, W.C.S. Genomic sequence analysis of EGFR regulation by microRNAs in lung cancer. Curr. Top. Med. Chem. 2012, 12, 920-926. [CrossRef]

50. Mohan, A.; Ansari, A.; Masroor, M.; Saxena, A.; Pandey, R.M.; Upadhyay, A.; Luthra, K.; Khilnani, G.C.; Jain, D.; Kumar, R.; et al. Measurement of Serum EGFR mRNA Expression is a Reliable Predictor of Treatment Response and Survival Outcomes in NonSmall Cell Lung Cancer. Asian Pac. J. Cancer Prev. 2020, 21, 3153-3163. [CrossRef]

51. Masroor, M.; Mir, R.; Javid, J.; Prasant, Y.; Imtiyaz, A.; Mariyam, Z.; Mohan, A.; Ray, P.C.; Saxena, A. Cell Free EGFR mRNA Expression and Implications for Survival and Metastasis in Non-Small Cell Lung Cancer Cases. Asian Pac. J. Cancer Prev. 2015, 16, 6445-6449. [CrossRef]

52. Acunzo, M.; Romano, G.; Palmieri, D.; Laganá, A.; Garofalo, M.; Balatti, V.; Drusco, A.; Chiariello, M.; Nana-Sinkam, P.; Croce, C.M. Cross-talk between MET and EGFR in non-small cell lung cancer involves miR-27a and Sprouty2. Proc. Natl. Acad. Sci. USA 2013, 110, 8573-8578. [CrossRef]

53. Zhang, Y.-W. The rationale for dual targeting MET and EGFR in non-small cell lung cancer. J. Cell Sci. Ther. 2013, 4, 4. [CrossRef]

54. Peng, S.; Wang, R.; Zhang, X.; Ma, Y.; Zhong, L.; Li, K.; Nishiyama, A.; Arai, S.; Yano, S.; Wang, W. EGFR-TKI resistance promotes immune escape in lung cancer via increased PD-L1 expression. Mol. Cancer 2019, 18, 165. [CrossRef]

55. Pan, J.-Y.; Zhang, F.; Sun, C.-C.; Li, S.-J.; Li, G.; Gong, F.-Y.; Bo, T.; He, J.; Hua, R.-X.; Hu, W.-D.; et al. miR-134: A Human Cancer Suppressor? Mol. Ther. Nucleic Acids 2017, 6, 140-149. [CrossRef]

56. Azad, F.M.; Naeli, P.; Malakootian, M.; Baradaran, A.; Tavallaei, M.O.M.T.O.; Ghanei, M.; Mowla, S. Two lung development-related microRNAs, miR-134 and miR-187, are differentially expressed in lung tumors. Gene 2016, 577, 221-226. [CrossRef]

57. Li, Y.-L.; Liu, X.-M.; Zhang, C.-Y.; Zhou, J.-B.; Shao, Y.; Liang, C.; Wang, H.-M.; Hua, Z.-Y.; Lu, S.-D.; Ma, Z.-L. MicroRNA34a/EGFR axis plays pivotal roles in lung tumorigenesis. Oncogenesis 2017, 6, e37. [CrossRef] [PubMed]

58. Kim, J.S.; Kim, E.J.; Lee, S.; Tan, X.; Liu, X.; Park, S.; Kang, K.; Yoon, J.-S.; Ko, Y.H.; Kurie, J.M.; et al. MiR-34a and miR-34b/c have distinct effects on the suppression of lung adenocarcinomas. Exp. Mol. Med. 2019, 51, 1-10. [CrossRef]

59. Shi, Y.; Liu, C.; Liu, X.; Tang, D.; Wang, J. The microRNA miR-34a inhibits non-small cell lung cancer (NSCLC) growth and the CD44hi stem-like NSCLC cells. PLoS ONE 2014, 9, e90022. [CrossRef] [PubMed]

60. Gallardo, E.; Navarro, A.; Viñolas, N.; Marrades, R.M.; Diaz, T.; Gel, B.; Quera, A.; Bandres, E.; Garcia-Foncillas, J.; Ramirez, J.; et al. miR-34a as a prognostic marker of relapse in surgically resected non-small-cell lung cancer. Carcinogenesis 2009, 30, 1903-1909. [CrossRef] [PubMed]

61. Xiong, R.; Sun, X.X.; Wu, H.R.; Xu, G.W.; Wang, G.X.; Sun, X.H.; Xu, M.Q.; Xie, M.R. Mechanism research of miR-34a regulates Axl in non-small-cell lung cancer with gefitinib-acquired resistance. Thorac. Cancer 2020, 11, 156-165. [CrossRef]

62. He, X.; Yang, A.; McDonald, D.G.; Riemer, E.C.; Vanek, K.N.; Schulte, B.A.; Wang, G.Y. MiR-34a modulates ionizing radiationinduced senescence in lung cancer cells. Oncotarget 2017, 8, 69797-69807. [CrossRef] [PubMed]

63. Song, C.; Lu, P.; Sun, G.; Yang, L.; Wang, Z.; Wang, Z. miR-34a sensitizes lung cancer cells to cisplatin via p53/miR-34a/MYCN axis. Biochem. Biophys. Res. Commun. 2017, 482, 22-27. [CrossRef]

64. Guo, N.; Zhao, Y.; Zhang, W.; Li, S.; Li, S.; Yu, J. MicroRNA-133a downregulated EGFR expression in human non-small cell lung cancer cells via AKT/ERK signaling. Oncol. Lett. 2018, 16, 6045-6050. [CrossRef]

65. Lan, D.; Zhang, X.; He, R.; Tang, R.; Li, P.; He, Q.; Chen, G. MiR-133a is downregulated in non-small cell lung cancer: A study of clinical significance. Eur. J. Med. Res. 2015, 20, 50. [CrossRef] [PubMed]

66. Wang, Y.; Li, J.; Chen, H.; Mo, Y.; Ye, H.; Luo, Y.; Guo, K.; Mai, Z.; Zhang, Y.; Chen, B.; et al. Down-regulation of miR-133a as a poor prognosticator in non-small cell lung cancer. Gene 2016, 591, 333-337. [CrossRef]

67. He, R.Q.; Li, X.J.; Liang, L.; Xie, Y.; Luo, D.Z.; Ma, J.; Peng, Z.G.; Hu, X.H.; Chen, G. The suppressive role of miR-542-5p in NSCLC: The evidence from clinical data and in vivo validation using a chick chorioallantoic membrane model. BMC Cancer 2017, 17, 655. [CrossRef] [PubMed]

68. Iacona, J.R.; Monteleone, N.J.; Lemenze, A.D.; Cornett, A.L.; Lutz, C.S. Transcriptomic studies provide insights into the tumor suppressive role of miR-146a-5p in non-small cell lung cancer (NSCLC) cells. RNA Biol. 2019, 16, 1721-1732. [CrossRef]

69. Zhao, Q.; Cao, J.; Wu, Y.C.; Liu, X.; Han, J.; Huang, X.C.; Jiang, L.H.; Hou, X.X.; Mao, W.M.; Ling, Z.Q. Circulating miRNAs is a potential marker for gefitinib sensitivity and correlation with EGFR mutational status in human lung cancers. Am. J. Cancer Res. 2015, 5, 1692-1705. [CrossRef]

70. Zhu, J.; Zeng, Y.; Li, W.; Qin, H.; Lei, Z.; Shen, D.; Gu, D.; Huang, J.A.; Liu, Z. CD73/NT5E is a target of miR-30a-5p and plays an important role in the pathogenesis of non-small cell lung cancer. Mol. Cancer 2017, 16, 34. [CrossRef] 
71. Amri, J.; Molaee, N.; Baazm, M.; Karami, H. Targeting epidermal growth factor receptor by MiRNA-145 inhibits cell growth and sensitizes NSCLC cells to erlotinib. Asian Pacific. J. Cancer Prev. 2019, 20, 2781-2787. [CrossRef] [PubMed]

72. Amri, J.; Molaee, N.; Karami, H. Up-regulation of MiRNA-125a-5p inhibits cell proliferation and increases EGFR-TKI induced apoptosis in lung cancer cells. Asian Pac. J. Cancer Prev. 2019, 20, 3361-3367. [CrossRef]

73. Meng, F.; Wang, F.; Wang, L.; Wong, S.C.C.; Cho, W.C.S.; Chan, L.W.C. MiR-30a-5p overexpression may overcome EGFR-inhibitor resistance through regulating PI3K/AKT signaling pathway in non-small cell lung cancer cell lines. Front. Genet. 2016, 7, 197. [CrossRef] [PubMed]

74. Wang, H.Y.; Liu, Y.N.; Wu, S.G.; Hsu, C.L.; Chang, T.H.; Tsai, M.F.; Lin, Y.T.; Shih, J.Y. MiR-200c-3p suppression is associated with development of acquired resistance to epidermal growth factor receptor (EGFR) tyrosine kinase inhibitors in EGFR mutant non-small cell lung cancer via a mediating epithelial-to-mesenchymal transition (EMT) process. Cancer Biomark. 2020, 28, 351-363. [CrossRef]

75. Ge, P.; Cao, L.; Chen, X.; Jing, R.; Yue, W. MiR-762 activation confers acquired resistance to gefitinib in non-small cell lung cancer. BMC Cancer 2019, 19, 1203. [CrossRef]

76. Gao, Y.; Fan, X.; Li, W.; Ping, W.; Deng, Y.; Fu, X. MiR-138-5p reverses gefitinib resistance in non-small cell lung cancer cells via negatively regulating $G$ protein-coupled receptor 124. Biochem. Biophys. Res. Commun. 2014, 446, 179-186. [CrossRef] [PubMed]

77. Zhang, W.C.; Wells, J.M.; Chow, K.H.; Huang, H.; Yuan, M.; Saxena, T.; Melnick, M.A.; Politi, K.; Asara, J.M.; Costa, D.B.; et al. miR-147b-mediated TCA cycle dysfunction and pseudohypoxia initiate drug tolerance to EGFR inhibitors in lung adenocarcinoma. Nat. Metab. 2019, 1, 460-474. [CrossRef]

78. Li, B.; Ren, S.; Li, X.; Wang, Y.; Garfield, D.; Zhou, S.; Chen, X.; Su, C.; Chen, M.; Kuang, P.; et al. MiR-21 overexpression is associated with acquired resistance of EGFR-TKI in non-small cell lung cancer. Lung Cancer 2014, 83, 146-153. [CrossRef]

79. Zhang, J.G.; Wang, J.J.; Zhao, F.; Liu, Q.; Jiang, K.; Yang, G.H. MicroRNA-21 (miR-21) represses tumor suppressor PTEN and promotes growth and invasion in non-small cell lung cancer (NSCLC). Clin. Chim. Acta 2010, 411, 846-852. [CrossRef]

80. Wang, S.; Su, X.; Bai, H.; Zhao, J.; Duan, J.; An, T.; Zhuo, M.; Wang, Z.; Wu, M.; Li, Z.; et al. Identification of plasma microRNA profiles for primary resistance to EGFR-TKIs in advanced non-small cell lung cancer (NSCLC) patients with EGFR activating mutation. J. Hematol. Oncol. 2015, 8, 127. [CrossRef]

81. Li, J.; Zheng, Y.; Sun, G.; Xiong, S. Restoration of miR-7 expression suppresses the growth of Lewis lung cancer cells by modulating epidermal growth factor receptor signaling. Oncol. Rep. 2014, 32, 2511-2516. [CrossRef] [PubMed]

82. Chou, Y.T.; Lin, H.H.; Lien, Y.C.; Wang, Y.H.; Hong, C.F.; Kao, Y.R.; Lin, S.C.; Chang, Y.C.; Lin, S.Y.; Chen, S.J.; et al. EGFR promotes lung tumorigenesis by activating miR-7 through a Ras/ERK/Myc pathway that targets the Ets2 transcriptional repressor ERF. Cancer Res. 2010, 70, 8822-8831. [CrossRef] [PubMed]

83. Guo, Y.H.; Gao, F.H.; Shi, J.; Yuan, H.H.; Jiang, B. EGFR-ERK signaling pathway down-regulates miRNA-145 in lung cancer cells. Zhonghua Zhong Liu Za Zhi 2013, 35, 187-192. [CrossRef]

84. Tao, S.; Ju, X.; Zhou, H.; Zeng, Q. Circulating microRNA-145 as a diagnostic biomarker for non-small-cell lung cancer: A systemic review and meta-analysis. Int. J. Biol. Markers 2020, 35, 51-60. [CrossRef]

85. Chen, G.; Umelo, I.A.; Lv, S.; Teugels, E.; Fostier, K.; Kronenberger, P.; Dewaele, A.; Sadones, J.; Geers, C.; De Grève, J. miR-146a Inhibits Cell Growth, Cell Migration and Induces Apoptosis in Non-Small Cell Lung Cancer Cells. PLoS ONE 2013, 8, e60317. [CrossRef]

86. Zhong, S.; Golpon, H.; Zardo, P.; Borlak, J. miRNAs in lung cancer. A systematic review identifies predictive and prognostic miRNA candidates for precision medicine in lung cancer. Transl. Res. 2021, 230, 164-196. [CrossRef]

87. Wani, J.; Majid, S.; Khan, A.; Arafah, A.; Ahmad, A.; Jan, B.; Shah, N.; Kazi, M.; Rehman, M. Clinico-Pathological Importance of miR-146a in Lung Cancer. Diagnostics 2021, 11, 274. [CrossRef]

88. Li, L.; Wang, D. MicroRNA-128-b regulates epidermal growth factor receptor expression in non-small cell lung cancer. Mol. Med. Rep. 2019, 20, 4803-4810. [CrossRef] [PubMed]

89. Zhang, L.; Cai, J.; Fang, L.; Huang, Y.; Li, R.; Xu, X.; Hu, Z.; Zhang, L.; Yang, Y.; Zhu, X.; et al. Simultaneous overactivation of Wnt $/ \beta$-catenin and TGF $\beta$ signalling by miR-128-3p confers chemoresistance-associated metastasis in NSCLC. Nat. Commun. 2017, 8, 15870. [CrossRef]

90. Li, F.; Li, H.; Li, S.; Lv, B.; Shi, J.; Yan, H.; Zhang, H.; He, Y. Long Non-coding RNA MIAT Mediates Non-small Cell Lung Cancer Development Through Regulating the miR-128-3p/PELI3 Axis. Biochem. Genet. 2020, 58, 867-882. [CrossRef]

91. Jiang, J.; Feng, X.; Zhou, W.; Wu, Y.; Yang, Y. MiR-128 reverses the gefitinib resistance of the lung cancer stem cells by inhibiting the c-met/PI3K/AKT pathway. Oncotarget 2016, 7, 73188-73199. [CrossRef] [PubMed]

92. Koh, H.; Park, H.; Chandimali, N.; Huynh, D.L.; Zhang, J.J.; Ghosh, M.; Gera, M.; Kim, N.; Bak, Y.; Yoon, D.Y.; et al. MicroRNA128 suppresses paclitaxel-resistant lung cancer by inhibiting MUC1-C and BMI-1 in cancer stem cells. Oncotarget 2017, 8, 110540-110551. [CrossRef] [PubMed]

93. Zhao, J.-G.; Men, W.-F.; Tang, J. MicroRNA-7 enhances cytotoxicity induced by gefitinib in non-small cell lung cancer via inhibiting the EGFR and IGF1R signalling pathways. Contemp. Oncol. 2015, 19, 201-206. [CrossRef]

94. Zhang, X.; Yang, D.; Wei, Y. Overexpressed CDR1as functions as an oncogene to promote the tumor progression via miR-7 in non-small-cell lung cancer. Onco. Targets. Ther. 2018, 11, 3979-3987. [CrossRef]

95. Li, Y.J.; Wang, C.H.; Zhou, Y.; Liao, Z.Y.; Zhu, S.F.; Hu, Y.; Chen, C.; Luo, J.M.; Wen, Z.K.; Xu, L. TLR9 signaling repressed tumor suppressor miR-7 expression through up-regulation of HuR in human lung cancer cells. Cancer Cell Int. 2013, 13, 90. [CrossRef] 
96. Xiao, H. MiR-7-5p suppresses tumor metastasis of non-small cell lung cancer by targeting NOVA2. Cell. Mol. Biol. Lett. 2019, 24, 1V. [CrossRef] [PubMed]

97. Lei, L.; Chen, C.; Zhao, J.; Wang, H.R.; Guo, M.; Zhou, Y.; Luo, J.; Zhang, J.; Xu, L. Targeted Expression of miR-7 Operated by TTF-1 Promoter Inhibited the Growth of Human Lung Cancer through the NDUFA4 Pathway. Mol. Ther. Nucleic Acids 2017, 6, 183-197. [CrossRef]

98. Jiang, W.; Xu, Z.; Yu, L.; Che, J.; Zhang, J.; Yang, J.; Dong, Y. MicroRNA-144-3p suppressed TGF- $\beta 1$-induced lung cancer cell invasion and adhesion by regulating the Src-Akt-Erk pathway. Cell Biol. Int. 2019, 44, 51-61. [CrossRef]

99. Chen, Y.-J.; Guo, Y.-N.; Shi, K.; Huang, H.-M.; Huang, S.-P.; Xu, W.-Q.; Li, Z.-Y.; Wei, K.-L.; Gan, T.-Q.; Chen, G. Down-regulation of microRNA-144-3p and its clinical value in non-small cell lung cancer: A comprehensive analysis based on microarray, miRNA-sequencing, and quantitative real-time PCR data. Respir. Res. 2019, 20, 48. [CrossRef]

100. Li, X.; Ma, C.; Luo, H.; Zhang, J.; Wang, J.; Guo, H. Identification of the differential expression of genes and upstream microRNAs in small cell lung cancer compared with normal lung based on bioinformatics analysis. Medicine 2020, 99, e19086. [CrossRef]

101. Kumar, S.; Sharawat, S.K.; Ali, A.; Gaur, V.; Malik, P.; Kumar, S.; Mohan, A.; Guleria, R. Identification of differentially expressed circulating serum microRNA for the diagnosis and prognosis of Indian non-small cell lung cancer patients. Curr. Probl. Cancer 2020, 44, 100540. [CrossRef] [PubMed]

102. Li, J.; Yu, M.; Liu, Z.; Liu, B. Clinical significance of serum miR-25 in non-small-cell lung cancer. Br. J. Biomed. Sci. 2019, 76, 111-116. [CrossRef] [PubMed]

103. Liu, B.; Sun, X. miR-25 promotes invasion of human non-small cell lung cancer via CDH1. Bioengineered 2019, 10, $271-281$. [CrossRef]

104. Wu, T.; Hu, H.; Zhang, T.; Jiang, L.; Li, X.; Liu, S.; Zheng, C.; Yan, G.; Chen, W.; Ning, Y.; et al. miR-25 Promotes Cell Proliferation, Migration, and Invasion of Non-Small-Cell Lung Cancer by Targeting the LATS2/YAP Signaling Pathway. Oxid. Med. Cell. Longev. 2019, 2019, 9719723. [CrossRef] [PubMed]

105. Wu, T.; Chen, W.; Kong, D.; Li, X.; Lu, H.; Liu, S.; Wang, J.; Du, L.; Kong, Q.; Huang, X.; et al. miR-25 targets the modulator of apoptosis 1 gene in lung cancer. Carcinogenesis 2015, 36, 925-935. [CrossRef]

106. Shen, Y.Y.; Cui, J.Y.; Yuan, J.; Wang, X. MiR-451a suppressed cell migration and invasion in non-small cell lung cancer through targeting ATF2. Eur. Rev. Med. Pharmacol. Sci. 2018, 22, 5554-5561. [CrossRef]

107. Yin, P.; Peng, R.; Peng, H.; Yao, L.; Sun, Y.; Wen, L.; Wu, T.; Zhou, J.; Zhang, Z. MiR-451 suppresses cell proliferation and metastasis in A549 lung cancer cells. Mol. Biotechnol. 2015, 57, 1-11. [CrossRef] [PubMed]

108. Liu, Y.; Li, H.; Li, L.H.; Tang, J.B.; Sheng, Y.L. Mir-451 inhibits proliferation and migration of non-small cell lung cancer cells via targeting LKB1/AMPK. Eur. Rev. Med. Pharmacol. Sci. 2019, 23, 274-280. [CrossRef]

109. Nie, R.; Niu, W.; Tang, T.; Zhang, J.; Zhang, X. Integrating microRNA expression, miRNA-mRNA regulation network and signal pathway: A novel strategy for lung cancer biomarker discovery. PeerJ 2021, 9, e12369. [CrossRef]

110. Monteleone, N.J.; Lutz, C.S. miR-708-5p enhances erlotinib/paclitaxel efficacy and overcomes chemoresistance in lung cancer cells. Oncotarget 2020, 11, 4699-4721. [CrossRef]

111. Alcantara, K.M.M.; Garcia, R.L. MicroRNA-92a promotes cell proliferation, migration and survival by directly targeting the tumor suppressor gene NF2 in colorectal and lung cancer cells. Oncol. Rep. 2019, 41, 2103-2116. [CrossRef]

112. Wang, Z.; Liu, L.; Du, Y.; Mi, Y.; Wang, L. The HNF1A-AS1/miR-92a-3p axis affects the radiosensitivity of non-small cell lung cancer by competitively regulating the JNK pathway. Cell Biol. Toxicol. 2021, 37, 715-729. [CrossRef]

113. Wei, J.; Jia, A.; Ma, L.; Wang, Y.; Qiu, L.; Xiao, B. MicroRNA-16 inhibits the proliferation and metastasis of human lung cancer cells by modulating the expression of YAP1. JBUON 2020, 25, 862-868. [PubMed]

114. Chen, T.M.; Xiao, Q.; Wang, X.J.; Wang, Z.Q.; Hu, J.W.; Zhang, Z.; Gong, Z.N.; Chen, S.L. miR-16 regulates proliferation and invasion of lung cancer cells via the ERK/MAPK signaling pathway by targeted inhibition of MAPK kinase 1 (MEK1). J. Int. Med. Res. 2019, 47, 5194-5204. [CrossRef] [PubMed]

115. Cui, D.; Feng, Y.; Shi, K.; Zhang, H.; Qian, R. Long non-coding RNA TRPM2-AS sponges microRNA-138-5p to activate epidermal growth factor receptor and PI3K/AKT signaling in non-small cell lung cancer. Ann. Transl. Med. 2020, 8, 1313. [CrossRef]

116. He, Q.; Fang, Y.; Lu, F.; Pan, J.; Wang, L.; Gong, W.; Fei, F.; Cui, J.; Zhong, J.; Hu, R.; et al. Analysis of differential expression profile of miRNA in peripheral blood of patients with lung cancer. J. Clin. Lab. Anal. 2019, 33, e23003. [CrossRef]

117. He, Y.; Ren, S.; Wang, Y.; Li, X.; Zhou, C.; Hirsch, F.R. Serum microRNAs improving the diagnostic accuracy in lung cancer presenting with pulmonary nodules. J. Thorac. Dis. 2018, 10, 5080-5085. [CrossRef] [PubMed]

118. Song, N.; Li, P.; Song, P.; Li, Y.; Zhou, S.; Su, Q.; Li, X.; Yu, Y.; Li, P.; Feng, M.; et al. MicroRNA-138-5p Suppresses Non-small Cell Lung Cancer Cells by Targeting PD-L1/PD-1 to Regulate Tumor Microenvironment. Front. Cell Dev. Biol. 2020, 8, 540. [CrossRef]

119. Yamaguchi, G.; Takanashi, M.; Tanaka, M.; Fujita, K.; Ohira, T.; Kuroda, M.; Ikeda, N. Isolation of miRNAs that target EGFR mRNA in human lung cancer. Biochem. Biophys. Res. Commun. 2012, 420, 411-416. [CrossRef] [PubMed]

120. Joerger, M.; Baty, F.; Früh, M.; Droege, C.; Stahel, R.; Betticher, D.; von Moos, R.; Ochsenbein, A.; Pless, M.; Gautschi, O.; et al. Circulating microRNA profiling in patients with advanced non-squamous NSCLC receiving bevacizumab/erlotinib followed by platinum-based chemotherapy at progression (SAKK 19/05). Lung Cancer 2014, 85, 306-313. [CrossRef]

121. Liu, B.; Li, J.; Zheng, M.; Ge, J.; Li, J.; Yu, P. MiR-542-3p exerts tumor suppressive functions in non-small cell lung cancer cells by upregulating FTSJ2. Life Sci. 2017, 188, 87-95. [CrossRef] 
122. Pan, L.; Wang, H.; Jiang, C.; Li, W.; Chen, Y.; Ying, G. Multiple MicroRNAs synergistically promote tolerance to epidermal growth factor receptor-targeted drugs in smoked lung cancer therapies. J. Cancer Res. Ther. 2019, 15, 876-881. [CrossRef]

123. Cho, W.C.S.; Chow, A.S.C.; Au, J.S.K. Restoration of tumour suppressor hsa-miR-145 inhibits cancer cell growth in lung adenocarcinoma patients with epidermal growth factor receptor mutation. Eur. J. Cancer 2009, 45, 2197-2206. [CrossRef] [PubMed]

124. Kitamura, K.; Seike, M.; Okano, T.; Matsuda, K.; Miyanaga, A.; Mizutani, H.; Noro, R.; Minegishi, Y.; Kubota, K.; Gemma, A. MiR-134/487b/655 cluster regulates TGF- $\beta$-induced epithelial- mesenchymal transition and drug resistance to gefitinib by targeting MAGI2 in Lung Adenocarcinoma Cells. Mol. Cancer Ther. 2014, 13, 444-453. [CrossRef]

125. Mou, K.; Gu, W.; Gu, C.; Zhang, J.; Qwang, W.; Ren, G.; Tian, J. Relationship between miR-7 expression and treatment outcomes with gefitinib in non-small cell lung cancer. Oncol. Lett. 2016, 12, 4613-4617. [CrossRef] [PubMed]

126. Cao, Q.; Mao, Z.-D.; Shi, Y.-J.; Chen, Y.; Sun, Y.; Zhang, Q.; Song, L.; Peng, L.-P. MicroRNA-7 inhibits cell proliferation, migration and invasion in human non-small cell lung cancer cells by targeting FAK through ERK/MAPK signaling pathway. Oncotarget 2016, 7, 77468-77481. [CrossRef] [PubMed]

127. Zhao, J.; Wang, K.; Liao, Z.; Li, Y.; Yang, H.; Chen, C.; Zhou, Y.; Tao, Y.; Guo, M.; Ren, T.; et al. Promoter mutation of tumor suppressor microRNA-7 is associated with poor prognosis of lung cancer. Mol. Clin. Oncol. 2015, 3, 1329-1336. [CrossRef]

128. Bagheri, A.; Khorshid, H.R.K.; Tavallaie, M.; Mowla, S.J.; Sherafatian, M.; Rashidi, M.; Zargari, M.; Boroujeni, M.E.; Hosseini, S.M. A panel of noncoding RNAs in non-small-cell lung cancer. J. Cell. Biochem. 2018, 120, 8280-8290. [CrossRef] [PubMed]

129. Francisco, L.M.; Sage, P.T.; Sharpe, A.H. The PD-1 pathway in tolerance and autoimmunity. Immunol. Rev. 2010, $236,219-242$. [CrossRef] [PubMed]

130. Huang, J.; Weng, Q.; Shi, Y.; Mao, W.; Zhao, Z.; Wu, R.; Ren, J.; Fang, S.; Lu, C.; Du, Y.; et al. MicroRNA-155-5p suppresses PD-L1 expression in lung adenocarcinoma. FEBS Open Bio 2020, 10, 1065-1071. [CrossRef] [PubMed]

131. Yu, H.; Boyle, T.A.; Zhou, C.; Rimm, D.L.; Hirsch, F.R. PD-L1 Expression in Lung Cancer. J. Thorac. Oncol. 2016, 11, 964-975. [CrossRef]

132. Hejleh, T.A.; Furqan, M.; Ballas, Z.; Clamon, G. The clinical significance of soluble PD-1 and PD-L1 in lung cancer. Crit. Rev. Oncol. Hematol. 2019, 143, 148-152. [CrossRef]

133. Tsoukalas, N.; Kiakou, M.; Tsapakidis, K.; Tolia, M.; Aravantinou-Fatorou, E.; Baxevanos, P.; Kyrgias, G.; Theocharis, S. PD-1 and PD-L1 as immunotherapy targets and biomarkers in non-small cell lung cancer. JBUON 2019, 24, 883-888.

134. Akbay, E.A.; Koyama, S.; Carretero, J.; Altabef, A.; Tchaicha, J.H.; Christensen, C.L.; Mikse, O.R.; Cherniack, A.D.; Beauchamp, E.M.; Pugh, T.J.; et al. Activation of the PD-1 pathway contributes to immune escape in EGFR-driven lung tumors. Cancer Discov. 2013, 3, 1355-1363. [CrossRef]

135. Zhang, Y.; Zeng, Y.; Liu, T.; Du, W.; Zhu, J.; Liu, Z.; Huang, J.-A. The canonical TGF- $\beta$ /Smad signalling pathway is involved in PD-L1-induced primary resistance to EGFR-TKIs in EGFR-mutant non-small-cell lung cancer. Respir. Res. 2019, 20, 164. [CrossRef] [PubMed]

136. Haratani, K.; Hayashi, H.; Tanaka, T.; Kaneda, H.; Togashi, Y.; Sakai, K.; Hayashi, K.; Tomida, S.; Chiba, Y.; Yonesaka, K.; et al. Tumor immune microenvironment and nivolumab efficacy in EGFR mutation-positive non-small-cell lung cancer based on T790M status after disease progression during EGFR-TKI treatment. Ann. Oncol. Off. J. Eur. Soc. Med. Oncol. 2017, 28, 1532-1539. [CrossRef] [PubMed]

137. Chen, N.; Fang, W.; Zhan, J.; Hong, S.; Tang, Y.; Kang, S.; Zhang, Y.; He, X.; Zhou, T.; Qin, T.; et al. Upregulation of PD-L1 by EGFR Activation Mediates the Immune Escape in EGFR-Driven NSCLC: Implication for Optional Immune Targeted Therapy for NSCLC Patients with EGFR Mutation. J. Thorac. Oncol. 2015, 10, 910-923. [CrossRef] [PubMed]

138. Guo, Y.; Song, J.; Wang, Y.; Huang, L.; Sun, L.; Zhao, J.; Zhang, S.; Jing, W.; Ma, J.; Han, C. Concurrent Genetic Alterations and Other Biomarkers Predict Treatment Efficacy of EGFR-TKIs in EGFR-Mutant Non-Small Cell Lung Cancer: A Review. Front. Oncol. 2020, 10, 610923. [CrossRef] [PubMed]

139. Talekar, M.; Trivedi, M.; Shah, P.; Ouyang, Q.; Oka, A.; Gandham, S.; Amiji, M.M. Combination wt-p53 and MicroRNA-125b transfection in a genetically engineered lung cancer model using dual CD44/EGFR-targeting nanoparticles. Mol. Ther. 2016, 24, 759-769. [CrossRef]

140. Cornett, A.L.; Lutz, C.S. Regulation of COX-2 expression by miR-146a in lung cancer cells. RNA 2014, 20, 1419-1430. [CrossRef] [PubMed]

141. Mohamed, R.H.; Pasha, H.F.; Gad, D.M.; Toam, M.M. miR-146a and miR-196a-2 genes polymorphisms and its circulating levels in lung cancer patients. J. Biochem. 2019, 220, 323-329. [CrossRef] [PubMed]

142. Wang, D.; Wang, Y.; Lin, Z.; Cai, L. Association between miRNA-146a polymorphism and lung cancer susceptibility: A metaanalysis involving 6506 cases and 6576 controls. Gene 2020, 757, 144940. [CrossRef]

143. Lopes, G.L.; Vattimo, E.; Junior, G.D.C. Identifying activating mutations in the EGFR gene: Prognostic and therapeutic implications in non-small cell lung cancer. J. Bras. Pneumol. 2015, 41, 365-375. [CrossRef]

144. Wee, P.; Wang, Z. Epidermal Growth Factor Receptor Cell Proliferation Signaling Pathways. Cancers 2017, 9, 52. [CrossRef]

145. Pancewicz-Wojtkiewicz, J. Epidermal growth factor receptor and notch signaling in non-small-cell lung cancer. Cancer Med. 2016, 5, 3572-3578. [CrossRef] [PubMed] 
146. Kitano, H.; Chung, J.-Y.; Ylaya, K.; Conway, C.; Takikita, M.; Fukuoka, J.; Doki, Y.; Hanaoka, J.; Hewitt, S.M. Profiling of phospho-AKT, phospho-mTOR, phospho-MAPK and EGFR in non-small cell lung cancer. J. Histochem. Cytochem. 2014, 62, 335-346. [CrossRef]

147. Wannesson, L.; Viteri, S.; Costa, C.; Karachaliou, N.; Molina-Vila, M.; Rosell, R. Signaling pathways modulating dependence of lung cancer on mutant epidermal growth factor receptor and mechanisms of intrinsic and acquired resistance to tyrosine kinase inhibitors. Curr. Pharm. Des. 2014, 20, 3883-3893. [CrossRef] [PubMed]

148. Yoshida, T.; Zhang, G.; Haura, E.B. Targeting epidermal growth factor receptor: Central signaling kinase in lung cancer. Biochem. Pharmacol. 2010, 80, 613-623. [CrossRef]

149. Pathak, A.; Rajappa, S.; Gore, A. Oncogenic drivers in nonsmall cell lung cancer and resistance to epidermal growth factor receptor tyrosine kinase inhibitors. Indian J. Cancer 2017, 54, S1-S8. [CrossRef]

150. Seshacharyulu, P.; Ponnusamy, M.P.; Haridas, D.; Jain, M.; Ganti, A.K.; Batra, S.K. Targeting the EGFR signaling pathway in cancer therapy. Expert Opin. Ther. Targets 2012, 16, 15-31. [CrossRef]

151. Petrelli, F.; Borgonovo, K.; Cabiddu, M.; Barni, S. Efficacy of EGFR tyrosine kinase inhibitors in patients with EGFR-mutated nonsmall-cell lung cancer: A meta-analysis of 13 randomized trials. Clin. Lung Cancer 2012, 13, 107-114. [CrossRef]

152. Sgambato, A.; Casaluce, F.; Maione, P.; Rossi, A.; Rossi, E.; Napolitano, A.; Palazzolo, G.; Bareschino, A.M.; Schettino, C.; Sacco, C.P.; et al. The Role of EGFR Tyrosine Kinase Inhibitors in the First-Line Treatment of Advanced Non Small Cell Lung Cancer Patients Harboring EGFR Mutation. Curr. Med. Chem. 2012, 19, 3337-3352. [CrossRef] [PubMed]

153. Paez, J.G. EGFR Mutations in Lung Cancer: Correlation with Clinical Response to Gefitinib Therapy. Science 2004, 304, 1497-1500. [CrossRef] [PubMed]

154. Subat, S.; Inamura, K.; Ninomiya, H.; Nagano, H.; Okumura, S.; Ishikawa, Y. Unique MicroRNA and mRNA Interactions in EGFR-Mutated Lung Adenocarcinoma. J. Clin. Med. 2018, 7, 419. [CrossRef]

155. Seike, M.; Goto, A.; Okano, T.; Bowman, E.D.; Schetter, A.J.; Horikawa, I.; Mathe, E.A.; Jen, J.; Yang, P.; Sugimura, H.; et al. MiR-21 is an EGFR-regulated anti-apoptotic factor in lung cancer in never-smokers. Proc. Natl. Acad. Sci. USA 2009, 106, 12085-12090. [CrossRef]

156. Bica-Pop, C.; Cojocneanu-Petric, R.; Magdo, L.; Raduly, L.; Gulei, D.; Berindan-Neagoe, I. Overview upon miR-21 in lung cancer: Focus on NSCLC. Cell. Mol. Life Sci. 2018, 75, 3539-3551. [CrossRef] [PubMed]

157. Gao, W.; Xu, J.; Liu, L.; Shen, H.; Zeng, H.; Shu, Y. A systematic-analysis of predicted miR-21 targets identifies a signature for lung cancer. Biomed. Pharmacother. 2012, 66, 21-28. [CrossRef] [PubMed]

158. Zheng, W.; Zhao, J.; Tao, Y.; Guo, M.; Ya, Z.; Chen, C.; Qin, N.; Zheng, J.; Luo, J.; Xu, L. MicroRNA-21: A promising biomarker for the prognosis and diagnosis of non-small cell lung cancer. Oncol. Lett. 2018, 16, 2777-2782. [CrossRef]

159. Yang, M.; Shen, H.; Qiu, C.; Ni, Y.; Wang, L.; Dong, W.; Liao, Y.; Du, J. High expression of miR-21 and miR-155 predicts recurrence and unfavourable survival in non-small cell lung cancer. Eur. J. Cancer 2013, 49, 604-615. [CrossRef]

160. Yang, J.-S.; Li, B.-J.; Lu, H.-W.; Chen, Y.; Lu, C.; Zhu, R.-X.; Liu, S.-H.; Yi, Q.-T.; Li, J.; Song, C.-H. Serum miR-152, miR-148a, miR-148b, and miR-21 as novel biomarkers in non-small cell lung cancer screening. Tumour Biol. 2015, 36, 3035-3042. [CrossRef]

161. Szpechcinski, A.; Florczuk, M.; Duk, K.; Zdral, A.; Rudzinski, S.; Bryl, M.; Czyzewicz, G.; Rudzinski, P.; Kupis, W.; Wojda, E.; et al. The expression of circulating miR-504 in plasma is associated with EGFR mutation status in non-small-cell lung carcinoma patients. Cell. Mol. Life Sci. 2019, 76, 3641-3656. [CrossRef]

162. Kim, J.Y.; Lee, W.J.; Park, H.Y.; Kim, A.; Shin, D.H.; Lee, C.H. Differential MicroRNA expression between EGFR T790M and L858R mutated lung cancer. J. Pathol. Transl. Med. 2018, 52, 275-282. [CrossRef] [PubMed]

163. Bjaanæs, M.M.; Halvorsen, A.R.; Solberg, S.; Jørgensen, L.; Dragani, T.A.; Galvan, A.; Colombo, F.; Anderlini, M.; Pastorino, U.; Kure, E.; et al. Unique microRNA-profiles in EGFR-mutated lung adenocarcinomas. Int. J. Cancer 2014, 135, 1812. [CrossRef] [PubMed]

164. Zhu, K.; Ding, H.; Wang, W.; Liao, Z.; Fu, Z.; Hong, Y.; Zhou, Y.; Zhang, C.-Y.; Chen, X. Tumor-suppressive miR-218-5p inhibits cancer cell proliferation and migration via EGFR in non-small cell lung cancer. Oncotarget 2016, 7, 28075-28085. [CrossRef] [PubMed]

165. Yang, Y.; Ding, L.; Hu, Q.; Xia, J.; Sun, J.; Wang, X.; Xiong, H.; Gurbani, D.; Li, L.; Liu, Y.; et al. MicroRNA-218 functions as a tumor suppressor in lung cancer by targeting IL-6/STAT3 and negatively correlates with poor prognosis. Mol. Cancer 2017, 16, 1-13. [CrossRef]

166. Dacic, S.; Kelly, L.; Shuai, Y.; Nikiforova, M.N. MiRNA expression profiling of lung adenocarcinomas: Correlation with mutational status. Mod. Pathol. 2010, 23, 1577-1582. [CrossRef]

167. Wischmann, F.; Götte, M.; Rezai, M.; Eich, H.T.; Greve, B. EGFR mediated Inhibition of miR-218 Maturation as cellular Radiation Response. In Proceedings of the Conference: 21st Annual Meeting of the German-Society-for-Radiation-Oncology, Hamburg, Germany, 25-28 June 2015; Springer: Berlin/Heidelberg, Germany, 2015; Volume 191.

168. Ma, W.; Kang, Y.; Ning, L.; Tan, J.; Wang, H.; Ying, Y. Identification of microRNAs involved in gefitinib resistance of non-small-cell lung cancer through the insulin-like growth factor receptor 1 signaling pathway. Exp. Ther. Med. 2017, 14, 2853-2862. [CrossRef]

169. Zhao, J.; Kelnar, K.; Bader, A.G. In-depth analysis shows synergy between erlotinib and miR-34a. PLoS ONE 2014, 9, e89105. [CrossRef] 
170. Hisakane, K.; Seike, M.; Sugano, T.; Yoshikawa, A.; Matsuda, K.; Takano, N.; Takahashi, S.; Noro, R.; Gemma, A. Exosome-derived miR-210 involved in resistance to osimertinib and epithelial-mesenchymal transition in EGFR mutant non-small cell lung cancer cells. Thorac. Cancer 2021, 12, 1690-1698. [CrossRef]

171. Wu, J.; Zheng, C.; Wang, Y.; Yang, Z.; Li, C.; Fang, W.; Jin, Y.; Hou, K.; Cheng, Y.; Qi, J.; et al. LncRNA APCDD1L-AS1 induces icotinib resistance by inhibition of EGFR autophagic degradation via the miR-1322/miR-1972/miR-324-3p-SIRT5 axis in lung adenocarcinoma. Biomark. Res. 2021, 9, 25. [CrossRef]

172. Liu, Y.-N.; Tsai, M.-F.; Wu, S.-G.; Chang, T.-H.; Tsai, T.-H.; Gow, C.-H.; Wang, H.-Y.; Shih, J.-Y. miR-146b-5p Enhances the Sensitivity of NSCLC to EGFR Tyrosine Kinase Inhibitors by Regulating the IRAK1/NF-kB Pathway. Mol. Ther. Nucleic Acids 2020, 22, 471-483. [CrossRef] [PubMed]

173. Liao, J.; Lin, J.; Lin, N.; Zou, C.; Kurata, J.; Lin, R.; He, Z.; Su, Y. Down-regulation of miR-214 reverses erlotinib resistance in non-small-cell lung cancer through up-regulating LHX6 expression. Sci. Rep. 2017, 7, 781. [CrossRef] [PubMed]

174. Antonicelli, A.; Cafarotti, S.; Indini, A.; Galli, A.; Russo, A.; Cesario, A.; Lococo, F.M.; Russo, P.; Mainini, A.F.; Bonifati, L.G.; et al. Egfr-targeted therapy for non-small cell lun cancer: Focus on EGFR oncogenic mutation. Int. J. Med. Sci. 2013, 10, 320-330. [CrossRef] [PubMed]

175. Narita, M.; Shimura, E.; Nagasawa, A.; Aiuchi, T.; Suda, Y.; Hamada, Y.; Ikegami, D.; Iwasawa, C.; Arakawa, K.; Igarashi, K.; et al. Chronic treatment of non-small-cell lung cancer cells with gefitinib leads to an epigenetic loss of epithelial properties associated with reductions in microRNA-155 and -200c. PLoS ONE 2017, 12, e0172115. [CrossRef]

176. Zhu, X.; Chen, L.; Liu, L.; Niu, X. EMT-Mediated Acquired EGFR-TKI Resistance in NSCLC: Mechanisms and Strategies. Front. Oncol. 2019, 9, 1044. [CrossRef]

177. Ye, R.; Tang, R.; Gan, S.; Li, R.; Cheng, Y.; Guo, L.; Zeng, C.; Sun, Y. New insights into long non-coding RNAs in non-small cell lung cancer. Biomed. Pharmacother. 2020, 131, 110775. [CrossRef] [PubMed]

178. Liu, L.; Shao, X.; Gao, W.; Zhang, Z.; Liu, P.; Wang, R.; Huang, P.; Yin, Y.; Shu, Y. MicroRNA-133b inhibits the growth of non-small-cell lung cancer by targeting the epidermal growth factor receptor. FEBS J. 2012, 279, 3800-3812. [CrossRef]

179. Kawana, S.; Saito, R.; Miki, Y.; Kimura, Y.; Abe, J.; Sato, I.; Endo, M.; Sugawara, S.; Sasano, H. Suppression of tumor immune microenvironment via microRNA-1 after epidermal growth factor receptor-tyrosine kinase inhibitor resistance acquirement in lung adenocarcinoma. Cancer Med. 2021, 10, 718-727. [CrossRef]

180. Marin, I.; Ofek, E.; Bar, J.; Prisant, N.; Perelman, M.; Avivi, C.; Lavy-Shahaf, G.; Onn, A.; Katz, R.; Barshack, I. MiR-21, EGFR and PTEN in non-small cell lung cancer: An in situ hybridisation and immunohistochemistry study. J. Clin. Pathol. 2020, 73, 636-641. [CrossRef]

181. Sun, W.; Yuan, X.; Tian, Y.; Wu, H.; Xu, H.; Hu, G.; Wu, K. Non-invasive approaches to monitor EGFR-TKI treatment in non-small-cell lung cancer. J. Hematol. Oncol. 2015, 8, 1-9. [CrossRef]

182. Bach, D.-H.; Kim, D.; Bae, S.Y.; Kim, W.K.; Hong, J.-Y.; Lee, H.-J.; Rajasekaran, N.; Kwon, S.; Fan, Y.; Luu, T.-T.; et al. Targeting Nicotinamide N-Methyltransferase and miR-449a in EGFR-TKI-Resistant Non-Small-Cell Lung Cancer Cells. Mol. Ther. Nucleic Acids 2018, 11, 455-467. [CrossRef]

183. Ma, Y.; Xu, P.; Mi, Y.; Wang, W.; Pan, X.; Wu, X.; He, Q.; Liu, H.; Tang, W.; An, H. Plasma MiRNA alterations between NSCLC patients harboring Del19 and L858R EGFR mutations. Oncotarget 2016, 7, 54965-54972. [CrossRef]

184. Hanafi, A.R.; Jayusman, A.M.; Alfasunu, S.; Sadewa, A.H.; Pramono, D.; Heriyanto, D.S.; Haryana, S.M. Serum MiRNA as predictive and prognosis biomarker in advanced stage non-small cell lung cancer in Indonesia. Chin. J. Lung Cancer 2020, 23, 321-332. [CrossRef]

185. Remon, J.; Alvarez-Berdugo, D.; Majem, M.; Moran, T.; Reguart, N.; Lianes, P. miRNA-197 and miRNA-184 are associated with brain metastasis in EGFR-mutant lung cancers. Clin. Transl. Oncol. 2016, 18, 153-159. [CrossRef] [PubMed]

186. Gober, M.K.; Collard, J.P.; Thompson, K.; Black, E.P. A microRNA signature of response to erlotinib is descriptive of TGF $\beta$ behaviour in NSCLC. Sci. Rep. 2017, 7, 4202. [CrossRef]

187. Bryant, J.L.; Britson, J.; Balko, J.M.; Willian, M.; Timmons, R.; Frolov, A.; Black, E.P. A microRNA gene expression signature predicts response to erlotinib in epithelial cancer cell lines and targets EMT. Br. J. Cancer 2012, 106, 148-156. [CrossRef]

188. Makris, D.; Scherpereel, A.; Copin, M.C.; Colin, G.; Brun, L.; Lafitte, J.J.; Marquette, C.H. Fatal interstitial lung disease associated with oral erlotinib therapy for lung cancer. BMC Cancer 2007, 7, 1-4. [CrossRef]

189. Ricciuti, B.; Mecca, C.; Cenci, M.; Leonardi, G.C.; Perrone, L.; Mencaroni, C.; Crino, L.; Grignani, F.; Baglivo, S.; Chiari, R.; et al. MiRNAs and resistance to EGFR-TKIs in EGFR-mutant non-small cell lung cancer: Beyond "traditional mechanisms" of resistance. Ecancermedicalscience 2015, 9, 569. [CrossRef]

190. Bisagni, A.; Pagano, M.; Maramotti, S.; Zanelli, F.; Bonacini, M.; Tagliavini, E.; Braglia, L.; Paci, M.; Mozzarelli, A.; Croci, S. Higher expression of miR-133b is associated with better efficacy of erlotinib as the second or third line in non-small cell lung cancer patients. PLoS ONE 2018, 13, e0196350. [CrossRef] [PubMed]

191. Haque, I.; Kawsar, H.I.; Motes, H.; Sharma, M.; Banerjee, S.; Banerjee, S.K.; Godwin, A.K.; Huang, C.H. Downregulation of miR-506-3p Facilitates EGFR-TKI Resistance through Induction of Sonic Hedgehog Signaling in Non-Small-Cell Lung Cancer Cell Lines. Int. J. Mol. Sci. 2020, 21, 1-19. [CrossRef]

192. Chen, J.; Cui, J.-D.; Guo, X.-T.; Cao, X.; Li, Q. Increased expression of miR-641 contributes to erlotinib resistance in non-small-cell lung cancer cells by targeting NF1. Cancer Med. 2018, 7, 1394-1403. [CrossRef] 
193. Zhao, Y.; Zheng, R.; Chen, J.; Ning, D. CircRNA CDR1as/miR-641/HOXA9 pathway regulated stemness contributes to cisplatin resistance in non-small cell lung cancer (NSCLC). Cancer Cell Int. 2020, 20, 289. [CrossRef]

194. Zhao, J.; Guerrero, A.; Kelnar, K.; Peltier, H.J.; Bader, A.G. Synergy between next generation EGFR tyrosine kinase inhibitors and miR-34a in the inhibition of non-small cell lung cancer. Lung Cancer 2017, 108, 96-102. [CrossRef] [PubMed]

195. Zhang, Z.; Lee, J.C.; Lin, L.; Olivas, V.; Au, V.; LaFramboise, T.; Abdel-Rahman, M.; Wang, X.; Levine, A.D.; Rho, J.K.; et al Activation of the AXL kinase causes resistance to EGFR-targeted therapy in lung cancer. Nat. Genet. 2012, 44, 852-860. [CrossRef]

196. He, L.; He, X.; Lim, L.P.; De Stanchina, E.; Xuan, Z.; Liang, Y.; Xue, W.; Zender, L.; Magnus, J.; Ridzon, D.; et al. A microRNA component of the p53 tumour suppressor network. Nature 2007, 447, 1130-1134. [CrossRef] [PubMed]

197. Mudduluru, G.; Ceppi, P.; Kumarswamy, R.; Scagliotti, G.V.; Papotti, M.; Allgayer, H. Regulation of Axl receptor tyrosine kinase expression by miR-34a and miR-199a/b in solid cancer. Oncogene 2011, 30, 2888-2899. [CrossRef]

198. Engelman, J.A.; Zejnullahu, K.; Mitsudomi, T.; Song, Y.; Hyland, C.; Park, J.O.; Lindeman, N.; Gale, C.-M.; Zhao, X.; Christensen, J.; et al. MET Amplification Leads to Gefitinib Resistance in Lung Cancer by Activating ERBB3 Signaling. Sci 2007, $316,1039$. [CrossRef]

199. Giaccone, G. The Role of Gefitinib in Lung Cancer Treatment. Clin. Cancer Res. 2004, 10, 4233s-4237s. [CrossRef] [PubMed]

200. Kita, K.; Fukuda, K.; Takahashi, H.; Tanimoto, A.; Nishiyama, A.; Arai, S.; Takeuchi, S.; Yamashita, K.; Ohtsubo, K.; Otani, S.; et al. Patient-derived xenograft models of non-small cell lung cancer for evaluating targeted drug sensitivity and resistance. Cancer Sci. 2019, 110, 3215-3224. [CrossRef] [PubMed]

201. Jiao, D.; Chen, J.; Li, Y.; Tang, X.; Wang, J.; Xu, W.; Song, J.; Li, Y.; Tao, H.; Chen, Q. miR-1-3p and miR-206 sensitizes HGF-induced gefitinib-resistant human lung cancer cells through inhibition of c-Met signalling and EMT. J. Cell. Mol. Med. 2018, 22, 3526-3536. [CrossRef]

202. Sun, C.; Gao, W.; Liu, J.; Cheng, H.; Hao, J. FGL1 regulates acquired resistance to Gefitinib by inhibiting apoptosis in non-small cell lung cancer. Respir. Res. 2020, 21, 210. [CrossRef]

203. Yu, G.; Zhong, N.; Chen, G.; Huang, B.; Wu, S. Downregulation of PEBP4, a target of miR-34a, sensitizes drug-resistant lung cancer cells. Tumour Biol. 2014, 35, 10341-10349. [CrossRef] [PubMed]

204. Janmaat, M.; Rodriguez, J.A.; Gallegos-Ruiz, M.; Kruyt, F.; Giaccone, G. Enhanced cytotoxicity induced by gefitinib and specific inhibitors of the Ras or phosphatidyl inositol-3 kinase pathways in non-small cell lung cancer cells. Int. J. Cancer 2006, 118, 209-214. [CrossRef] [PubMed]

205. Shao, C.; Yang, F.; Qin, Z.; Jing, X.; Shu, Y.; Shen, H. The value of miR-155 as a biomarker for the diagnosis and prognosis of lung cancer: A systematic review with meta-analysis. BMC Cancer 2019, 19, 1103. [CrossRef] [PubMed]

206. Donnem, T.; Eklo, K.; Berg, T.; Sorbye, S.W.; Lonvik, K.; Al-Saad, S.; Al-Shibli, K.; Andersen, S.; Stenvold, H.; Bremnes, R.M.; et al. Prognostic impact of MiR-155 in non-small cell lung cancer evaluated by in situ hybridization. J. Transl. Med. 2011, 9, 6. [CrossRef]

207. Xie, K.; Ma, H.; Liang, C.; Wang, C.; Qin, N.; Shen, W.; Gu, Y.; Yan, C.; Zhang, K.; Dai, N.; et al. A functional variant in miR-155 regulation region contributes to lung cancer risk and survival. Oncotarget 2015, 6, 42781-42792. [CrossRef] [PubMed]

208. Huang, Y.; Bao, T.; Li, Z.; Ji, G.; Zhang, L. Function of miR-200a in proliferation and apoptosis of non-small cell lung cancer cells. Oncol. Lett. 2020, 20, 1256-1262. [CrossRef]

209. Liu, C.; Hu, W.; Li, L.-L.; Wang, Y.-X.; Zhou, Q.; Zhang, F.; Song-Yang, Y.-Y.; Zhu, W.; Sun, C.-C.; Li, D.-J. Roles of miR-200 family members in lung cancer: More than tumor suppressors. Future Oncol. 2018, 14, 2875-2886. [CrossRef] [PubMed]

210. Yin, Y.; Song, W.W.; Wang, Y.; Zhao, W.; Wu, J.; Xu, W. MicroRNA-200 families and prognostic value in various carcinomas: A systematic review and meta-analysis. Aging Med. Milt. 2018, 1, 39-45. [CrossRef]

211. Wang, S.-K.; Lin, K.; Xu, T.; He, B.-S.; Pan, Y.-Q.; Sun, H.-L.; Peng, H.-X.; Hu, X.-X. MicroRNA expression profiles predict progression and clinical outcome in lung adenocarcinoma. Onco. Targets. Ther. 2016, 9, 5679-5692. [CrossRef]

212. Chen, Q.; Chen, S.; Zhao, J.; Zhou, Y.; Xu, L. MicroRNA-126: A new and promising player in lung cancer. Oncol. Lett. 2021, 21, 1-11. [CrossRef]

213. Zhou, W.; Nie, J.; Zhang, D. Differential expression of miR-126-5p in lung adenocarcinoma and the possible mechanism. Nan Fang Yi Ke Da Xue Xue Bao 2019, 39, 1186-1190. [CrossRef]

214. Zheng, W.; Zhou, Y.; Lu, J.; Xu, H.; Lei, L.; Chen, C.; Zhao, J.; Xu, L. The prognostic value of miR-126 expression in non-small-cell lung cancer: A meta-analysis. Cancer Cell Int. 2017, 17, 71. [CrossRef] [PubMed]

215. Xing, L.; Ning, Z.; Jun, D.; Lu, Z.; Xin-Ting, F.; Yu, W.; Jing-Kang, H. MicroRNA-138 targets SOX4 to regulate the proliferation and metastasis of human lung cancer cells. JBUON 2020, 25, 835-841.

216. Tang, X.; Jiang, J.; Zhu, J.; He, N.; Tan, J. HOXA4-regulated miR-138 suppresses proliferation and gefitinib resistance in non-small cell lung cancer. Mol. Genet. Genomics 2019, 294, 85-93. [CrossRef]

217. Han, Z.; Zhou, X.; Li, S.; Qin, Y.; Chen, Y.; Liu, H. Inhibition of miR-23a increases the sensitivity of lung cancer stem cells to erlotinib through PTEN/PI3K/Akt pathway. Oncol. Rep. 2017, 38, 3064-3070. [CrossRef] [PubMed]

218. Wang, Y.-S.; Wang, Y.-H.; Xia, H.-P.; Zhou, S.-W.; Schmid-Bindert, G.; Zhou, C.-C. MicroRNA-214 regulates the acquired resistance to gefitinib via the PTEN/AKT pathway in EGFR-mutant cell lines. Asian Pac. J. Cancer Prev. 2012, 13, 255-260. [CrossRef]

219. Yin, J.; Hu, W.; Pan, L.; Fu, W.; Dai, L.; Jiang, Z.; Zhang, F.; Zhao, J. let-7 and miR-17 promote self-renewal and drive gefitinib resistance in non-small cell lung cancer. Oncol. Rep. 2019, 42, 495-508. [CrossRef] 
220. Wang, F.; Meng, F.; Wong, S.C.C.; Cho, W.C.; Yang, S.; Chan, L.W. Combination therapy of gefitinib and miR-30a-5p may overcome acquired drug resistance through regulating the PI3K/AKT pathway in non-small cell lung cancer. Ther. Adv. Respir. Dis. 2020, 14, 1753466620915156. [CrossRef]

221. Wang, H.; Kanmangne, D.; Li, R.; Qian, Z.; Xia, X.; Wang, X.; Wang, T. miR-30a-3p suppresses the proliferation and migration of lung adenocarcinoma cells by downregulating CNPY2. Oncol. Rep. 2020, 43, 646-654. [CrossRef] [PubMed]

222. Guan, Y.; Rao, Z.; Chen, C. miR-30a suppresses lung cancer progression by targeting SIRT1. Oncotarget 2017, 9, 4924-4934. [CrossRef] [PubMed]

223. Xu, X.; Jin, S.; Ma, Y.; Fan, Z.; Yan, Z.; Li, W.; Song, Q.; You, W.; Lyu, Z.; Song, Y.; et al. miR-30a-5p enhances paclitaxel sensitivity in non-small cell lung cancer through targeting BCL-2 expression. J. Mol. Med. 2017, 95, 861-871. [CrossRef]

224. Luan, N.; Wang, Y.; Liu, X. Absent expression of miR-30a promotes the growth of lung cancer cells by targeting MEF2D. Oncol. Lett. 2018, 16, 1173-1179. [CrossRef]

225. Li, Q.; Wang, Y.; He, J. MiR-133a-3p attenuates resistance of non-small cell lung cancer cells to gefitinib by targeting SPAG5. J. Clin. Lab. Anal. 2021, 35, e23853. [CrossRef] [PubMed]

226. Yue, J.; Lv, D.; Wang, C.; Li, L.; Zhao, Q.; Chen, H.; Xu, L. Epigenetic silencing of miR-483-3p promotes acquired gefitinib resistance and EMT in EGFR-mutant NSCLC by targeting integrin $\beta 3$. Oncogene 2018, 37, 4300-4312. [CrossRef]

227. Zhu, J.; Qi, Y.; Wu, J.; Shi, M.; Feng, J.; Chen, L. Evaluation of plasma microRNA levels to predict insensitivity of patients with advanced lung adenocarcinomas to pemetrexed and platinum. Oncol. Lett. 2016, 12, 4829-4837. [CrossRef] [PubMed]

228. Du, W.; Sun, L.; Liu, T.; Zhu, J.; Zeng, Y.; Zhang, Y.; Wang, X.; Liu, Z.; Huang, J.-A. The miR-625-3p/AXL axis induces non-T790M acquired resistance to EGFR-TKI via activation of the TGF- $\beta /$ Smad pathway and EMT in EGFR-mutant non-small cell lung cancer. Oncol. Rep. 2020, 44, 185-195. [CrossRef] [PubMed]

229. Yang, X.; Zhang, Q.; Zhang, M.; Su, W.; Wang, Z.; Li, Y.; Zhang, J.; Beer, D.G.; Yang, S.; Chen, G. Serum microRNA Signature Is Capable of Early Diagnosis for Non-Small Cell Lung Cancer. Int. J. Biol. Sci. 2019, 15, 1712-1722. [CrossRef]

230. Raponi, M.; Dossey, L.; Jatkoe, T.; Wu, X.; Chen, G.; Fan, H.; Beer, D.G. MicroRNA classifiers for predicting prognosis of squamous cell lung cancer. Cancer Res. 2009, 69, 5776-5783. [CrossRef] [PubMed]

231. Heegaard, N.H.H.; Schetter, A.J.; Welsh, J.A.; Yoneda, M.; Bowman, E.D.; Harris, C.C. Circulating micro-RNA expression profiles in early stage nonsmall cell lung cancer. Int. J. Cancer 2012, 130, 1378-1386. [CrossRef]

232. Cinegaglia, N.C.; Andrade, S.C.S.; Tokar, T.; Pinheiro, M.; Severino, F.E.; Oliveira, R.A.; Hasimoto, E.N.; Cataneo, D.C.; Cataneo, A.J.M.; Defaveri, J.; et al. Integrative transcriptome analysis identifies deregulated microRNA-transcription factor networks in lung adenocarcinoma. Oncotarget 2016, 7, 28920-28934. [CrossRef]

233. Fan, J.; Xu, G.; Chang, Z.; Zhu, L.; Yao, J. miR-210 transferred by lung cancer cell-derived exosomes may act as proangiogenic factor in cancer-associated fibroblasts by modulating JAK2/STAT3 pathway. Clin. Sci. 2020, 134, 807-825. [CrossRef] [PubMed]

234. Zhang, X.; Sai, B.; Wang, F.; Wang, L.; Wang, Y.; Zheng, L.; Li, G.; Tang, J.; Xiang, J. Hypoxic BMSC-derived exosomal miRNAs promote metastasis of lung cancer cells via STAT3-induced EMT. Mol. Cancer 2019, 18, 40. [CrossRef] [PubMed]

235. Yang, F.; Yan, Y.; Yang, Y.; Hong, X.; Wang, M.; Yang, Z.; Liu, B.; Ye, L. MiR-210 in exosomes derived from CAFs promotes non-small cell lung cancer migration and invasion through PTEN/PI3K/AKT pathway. Cell. Signal. 2020, 73, 109675. [CrossRef]

236. Zhang, J.; Li, D.; Zhang, Y.; Ding, Z.; Zheng, Y.; Chen, S.; Wan, Y. Integrative analysis of mRNA and miRNA expression profiles reveals seven potential diagnostic biomarkers for non-small cell lung cancer. Oncol. Rep. 2020, 43, 99-112. [CrossRef]

237. Xie, S.; Liu, G.; Huang, J.; Hu, H.B.; Jiang, W. miR-210 promotes lung adenocarcinoma proliferation, migration, and invasion by targeting lysyl oxidase-like 4. J. Cell. Physiol. 2019, 234, 14050-14057. [CrossRef] [PubMed]

238. Xie, N.; Fei, X.; Liu, S.; Liao, J.; Li, Y. LncRNA LOXL1-AS1 promotes invasion and proliferation of non-small-cell lung cancer through targeting miR-324-3p. Am. J. Transl. Res. 2019, 11, 6403. [PubMed]

239. Lin, M.H.; Chen, Y.Z.; Lee, M.Y.; Weng, K.P.; Chang, H.T.; Yu, S.Y.; Dong, B.J.; Kuo, F.R.; Hung, L.T.; Liu, L.F.; et al. Comprehensive identification of microRNA arm selection preference in lung cancer: miR-324-5p and -3p serve oncogenic functions in lung cancer. Oncol. Lett. 2018, 15, 9818-9826. [CrossRef] 